Review

\title{
Innate Lymphoid Cells: Important Regulators of Host-Bacteria Interaction for Border Defense
}

\author{
Katharina Beck ${ }^{1}$, Hiroshi Ohno ${ }^{1,2,3,4}$ and Naoko Satoh-Takayama ${ }^{1,2, *}$ \\ 1 Laboratory for Intestinal Ecosystem, Center for Integrative Medical Sciences, RIKEN, 1-7-22 Suehiro-cho, \\ Tsurumi-ku, Yokohama 230-0045, Japan; katharina.beck@riken.jp (K.B.); hiroshi.ohno@riken.jp (H.O.) \\ 2 Immunobiology Laboratory, Graduate School of Medical Life Science, Yokohama City University, \\ 1-7-29 Suehiro-cho, Tsurumi-ku, Yokohama 230-0045, Japan \\ 3 Intestinal Microbiota Project, Kanagawa Institute of Industrial Science and Technology, 3-2-1 Sakado, \\ Takatsu-ku, Kawasaki 213-0012, Japan \\ 4 Laboratory for Immune Regulation, Graduate School of Medicine, Chiba University, 1-8-1 Inohana, Chuo-ku, \\ Chiba 260-8670, Japan \\ * Correspondence: naoko.satoh@riken.jp; Tel.: +81-45-503-7074
}

Received: 30 July 2020; Accepted: 31 August 2020; Published: 2 September 2020

check for updates

\begin{abstract}
Innate lymphoid cells (ILCs) are a recently discovered type of innate immune lymphocyte. They include three different groups classified by the nature of the transcription factors required for their development and by the cytokines they produce. ILCs mainly reside in tissues close to the mucosal barrier such as the respiratory and gastrointestinal tracts. Due to their close proximity to the mucosal surface, ILCs are exposed to a variety of both commensal and pathogenic bacteria. Under non-pathological conditions, ILCs have been shown to be important regulators for the maintenance of tissue homeostasis by mutual interactions with the microbiome. Besides these important functions at homeostasis, several studies have also provided emerging evidence that ILCs contribute to defense against pathogenic bacterial infection by responding rapidly to the pathogens as well as orchestrating other immune cells. In this review, we summarize recent advances in our understanding of the interactions of ILCs and bacteria, with special focus on the function of the different ILC subsets in bacterial infections.
\end{abstract}

Keywords: innate lymphoid cells (ILCs); bacterial infection; mucosal defense; microbiota; intestinal homeostasis

\section{Introduction}

Mucosal surfaces are confronted with an enormous number of both commensal and pathogenic bacteria, and the immune system has evolved various mechanisms for maintaining and shaping the indispensable symbiosis between the host and the microbiota. However, some bacteria have devised mechanisms to overcome the host protective responses and thereby can cause severe infections. In recent years, innate lymphoid cells (ILCs) have been shown to play a critical role in maintaining homeostasis and in protective immunity, as well as being important mediators between the microbiota and the adaptive immune system. ILCs are integrated in all sites of the mucosal tissues, although a limited group of ILCs can be found in almost all organs. ILC-mediated defense is characterized by a rapid reaction achieved by cytokine release. Here we will describe how the responses of ILCs are regulated by microorganisms, including non-pathogenic bacteria, as well as their functional role in bacteria-triggered diseases. 


\section{Definition of ILC Subsets and General Functions}

All ILCs originate from a common innate lymphoid progenitor (CLP) and the later stage ILC progenitor cell (ILCP). Based on their differentiation and function, ILCs can be divided into three subgroups: ILC1, ILC2, and ILC3 which are considered as innate analogues of the three major CD4 ${ }^{+}$ $\mathrm{T}$ effector cells, Th1, Th2, and Th17 because of their similar functions [1]. Unlike these adaptive T cells, ILCs do not express antigen receptors, but instead they display several activating and inhibitory receptors. ILCs can be subdivided based on the key transcription factors that control their cytokine profiles and signature functions.

By analogy to Th1 cells, ILC1 mediate type 1 immunity against tumors and intracellular pathogens such as viruses and certain bacteria. ILC1 mediate their effects through interferon gamma (IFN- $\gamma$ ) and tumor necrosis factor (TNF)- $\alpha$ cytokine production, which depends on the transcription factor T-box expressed in T cells (T-bet) [1]. Initially, it has been suggested to include conventional natural killer (cNK) cells in the same group as ILC1 [2], but now they are defined as two groups [1]. NK cells differentiate from a common innate progenitor (CILP) but differ from ILC1 in their dependence on eomesodermin (EOMES) during differentiation $[1,3,4]$. Similar to ILC1, cNK express IFN- $\gamma$ but additionally they produce perforin and granzyme. Both ILC1 and cNK cells function collaboratively as the innate counterparts of cytotoxic $\mathrm{CD}^{+} \mathrm{T}$ cells [5].

ILC2 mediate a type 2 immune response, which is characterized by their production of the cytokines IL-4, IL-5, IL-9, and IL-13, as well as amphiregulin [6-8]. The function and development of ILC2 rely on the expression of the transcription factor GATA3 and ROR $\alpha$ [9-11]. They express the IL-33 receptor component ST2, which provides the basis for their activation by IL-25 and IL-33. ILC2 have recently been shown to play a crucial role in defense against extracellular parasites [12-14], in allergic-responses [15] and in tissue repair [16,17]. Dysregulation of ILC2 is associated with allergic diseases like asthma and atopic dermatitis [18].

ILC3 are characterized as the Th17 equivalent innate immune cells due to their production of IL-22 and/or IL-17. ILC3 are highly abundant in the intestine where they play a crucial role in intestinal immunity including the maintenance of mucosal barrier integrity and microbiota-host homeostasis. It is well-documented that retinoic acid-related orphan receptor gamma $t(R O R \gamma t)$ is essential for ILC3 development and is indispensable for ILC3 determination $[1,19,20]$. ILC3 can be divided into at least three subpopulations based on the expression of NKp46, also known as natural cytotoxic receptor 1 (NCR1), and CCR6. NKp46 ${ }^{+} \mathrm{CCR}^{-}$ILC3 mainly produce IL-22 rather than IL-17 in response to IL-23 and IL-1 $\beta$ [21]. In contrast, NKp46 ${ }^{-} \mathrm{CCR} 6^{+}$ILC3, known as lymphoid tissue inducer (LTi) cells due to their functional contribution to lymphoid organ formation, produce both IL-22 and IL-17 and additionally lymphotoxins [21]. LTi cells derive from an earlier common progenitor (CHILP) but differ in the developmental path from other ILC3 [1,3,4]. The third subgroup lacking CCR6 and NKp46 expression is a mixed population, which additionally co-express the transcription factor T-bet and also includes ex-NKp46 ${ }^{+}$ILC3 [22,23].

Even though ILCs are characterized by the expression of specific transcription factors, lineage tracing studies have provided clear evidence that there is plasticity among the ILC subgroups $[1,24]$. It has been shown that ILCs have an ability to adapt to the local environment by changing their transcription profiles. ILCs, including NK cells, are initially derived from the same progenitor. Circulating naïve ILCs, which are referred to as $\mathrm{CD} 127^{+} \mathrm{CD} 117^{+}$ILCs, were recently found in human peripheral blood but can also be found in the tissue where they may go through further maturation [25]. The capacity to re-shape the subtypes upon microenvironmental changes and specific cytokine exposure has been shown to result in changes in ILC identity and in functional capacity. For instance, NKp46 ${ }^{-} \mathrm{CCR}^{-}$double negative ILC3 are able to convert into NK1.1 ${ }^{+} \mathrm{NKp} 46^{+}$ILC1 [22,26,27]. Moreover, the conversion of ILC2 into IFN- $\gamma$-producing ILC1 has been reported recently [28-30]. This capacity for plasticity might be the reason for the complex heterogeneity of ILCs, complicating the identification of the specific role of each subgroup in diseases. 
Murine ILC subsets have been widely shown to be tissue-specific due to the organ-specific microenvironment [31,32]. The spatial distribution of ILCs in humans and mice is dissimilar and big efforts have been made to specify the ILC distribution in human non-pathological conditions [33,34]. Especially ILC1 showed brought heterogeneity throughout the tissues [33], thus the distribution of ILCs in different organs/tissues requires further studies. Here, we mainly review the function of mature ILCs, which are mostly tissue-resident in each organ, with a special focus on bacterial infection or colonization.

\section{Infections of the Gastrointestinal Tract}

\subsection{ILC1 and NK Cells}

ILC1, including NK cells, are mainly involved in the defense against tumors and intracellular pathogens such as viruses. Information about the interaction of ILC1 with bacteria had so far been limited, but has become better understood because of several recent reports [1,35-47]. A human study in which colonic lamina propria-derived ILC1 were exposed to commensal gut bacteria, interestingly showed that only Gram-negative bacteria induced the production of IFN- $\gamma$. CD11c ${ }^{+}$myeloid dendritic cells (mDC) mediate ILC1 stimulation by releasing the cytokines IL-12p70, IL-18, and IL-1 $\beta$, resulting in ILC1-derived production of granzyme B and IFN- $\gamma$ [35]. Moreover, in vitro experiments indicated that IFN- $\gamma$ could promote the translocation of Escherichia coli (E.coli) due to cytokine-dependent tight junction disruption [36]. Consequently, ILC1 are currently thought to have a high priority in defense against pathogenic bacteria and are mainly associated with bacterial infections of the gastrointestinal tract.

\subsubsection{Citrobacter rodentium}

Infection with the extracellular enteric mouse-specific pathogen Citrobacter rodentium (C. rodentium) leads to gastrointestinal lesions in the gut mucosa that are similar to symptoms caused by the human pathogens enteropathogenic E. coli (EPEC) and enterohaemorrhagic E. coli (EHEC). Consequently, C. rodentium has been widely used as a model to study the host response to infections as well as the interactions of pathogen, host and microbiota [37]. C. rodentium infection in mice affects the caecum and the colon, where it causes acute inflammation and crypt hyperplasia.

IFN- $\gamma$ producing ILC1 and NK cells have been shown to be important for protection against $C$. rodentium infection. Indeed, NK cell-depleted mice had a higher bacterial load accompanied by more severe inflammation. They also had lower levels of IFN- $\gamma$, TNF- $\alpha$, IL-12, and pathogen-specific IgG in the colon, and a delay in homing of IFN- $\gamma^{+} \mathrm{CD} 4^{+} \mathrm{T}$ cells to the intestine. These findings indicate that NK cells promote bacterial clearance through antibody production against $C$. rodentium [38]. Moreover, C. rodentium infection leads to expanded ILC1 number in the small intestine [39], which might be due to ILC1/3 plasticity in the gut.

\subsubsection{Clostridium difficile}

Infections with Clostridium difficile (C. difficile) mainly occur in patients with disturbed gut microbiota as a consequence of broad-spectrum antibiotics therapy [40]. Pathogenesis evolves by ingestion of $C$. difficile spores, which germinate in the presence of bile acids and other signals like $\mathrm{Ca}^{2+}$ and amino acid derivates in the dysbiotic gut. The bacteria colonize and adhere to the epithelial cells, where they produce toxin A and B and, in some strains, binary toxin 'CDT'. This leads to the onset of disease due to disruption of the actin cytoskeleton, epithelial cell rounding and cell death. The infection causes a wide spectrum of symptoms ranging from mild diarrhea to toxic megacolon and even death $[40,41]$.

A study using C. difficile-infected C57BL/6Rag1-1- mice, which lack $\mathrm{T}$ and $\mathrm{B}$ cells, showed upregulation of ILC1 and ILC3 associated proteins such as IFN- $\gamma$, TNF- $\alpha$ and Nos2 (ILC1-derived) as well as IL-22, IL-17a, and RegIII $\gamma$ (ILC3-derived). The further analysis of $\mathrm{Rag}^{-/-} \mathrm{Il2} \mathrm{rg}^{-/-}$(also termed 
$\mathrm{Ra}^{-/-} \gamma \mathrm{C}^{-/-}$) mice, which also lack all innate lymphoid cells, showed increased infection susceptibility to $C$. difficile, which could be rescued by ILC transfer. Especially, the loss of IFN- $\gamma$ or T-bet-expressing ILC1 in Rag1 ${ }^{-/-}$mice was associated with increased infection susceptibility, revealing a protective role of ILC1 in C. difficile infection [42].

\subsubsection{Salmonella spp.}

Salmonella typhimurium (S. typhimurium) and S. enteritidis are pathogenic bacteria that cause gastroenteritis, mostly after the ingestion of contaminated food. The symptoms include nausea, vomiting, fever, diarrhea, and cramping. The infection usually self-resolves after several days, which might be one reason for the lack of human studies on the role of ILCs in S. typhimurium infection. In the mouse model, $S$. typhimurium infection can only be induced by prior streptomycin treatment [43]. Immune defense against $S$. typhimurium infection is characterized by increased IFN- $\gamma$ secretion [44], which induces the defense mechanisms of other immune cells [45] and also helps to stimulate mucus secretion from goblet cells [46]. Loss of NK cells and the subsequent absence of protective IFN- $\gamma$ secretion has been shown to increase susceptibility in the murine $S$. typhimurium infection model [44,47]. The study by Castleman et al. [35] further indicated that the in vitro exposure of commensal Gram-negative and pathogenic $S$. typhimurium to human colonic lamina propria cells led to increased IFN- $\gamma$ expression by ILC1 and NK cells, which was mediated by the cytokines IL-12p70, IL-18, and IL-1 $\beta$ [22].

\subsection{ILC2}

In the past, ILC2 have been mainly associated with wound repair and helminth infections rather than bacterial infections [48-50]. Through induction of goblet cell differentiation, they promote mucin secretion and, thereby, strengthening the secondary barrier of the intestine against pathogens [51,52]. However, more recently ILC2 are also gaining attention for their role during bacterial infection. ILC2-activating factors such as TSLP are influenced by the microbiota, thus suggesting possible interaction with and modulation of ILC2 functions [53]. An in vitro study on human circulating ILC2 showed that ILC2 express Toll-like receptors (TLR) 1, 4, and 6. Upon TLR stimulation, ILC2 induced immunoglobulin (IgM, IgG, IgA, and IgE) production by co-cultured B cells, which in turn shaped the composition of the microbiota [54]. We recently reported a similar mechanism for ILC2 in the stomach, where ILC2 are the most abundant ILC [55].

\subsubsection{Clostridium difficile}

As mentioned above, $C$. difficile infection leads to epithelial damage due to the release of toxins and mainly involves the ILC1 and ILC3 subsets. However, recent studies further reveal the importance of ILC2 for C. difficile infection prognosis. Frisbee et al. observed upregulation of IL-33 production during C. difficile infection, both in mice and humans [56]. IL-33 activates ILC2, which further protect from toxin-mediated epithelial damage via recruitment of eosinophils. $\mathrm{Rag}^{-/-} \mathrm{\gamma C}^{-/-}$mice showed a worse prognosis after $C$. difficile infection, which could be reversed by ex vivo transfer of ILC2. These reports suggested that ILC2 activation, triggered by IL-33, is also involved as an important defense mechanism against $C$. difficile-derived colitis [56].

\subsubsection{Helicobacter pylori}

Gastric Helicobacter pylori (H. pylori) infection is highly prevalent in humans. Chronic infection has been associated with the development of pathologies such as gastric ulcers and gastric cancer. It has been recently observed that $H$. pylori infection results in an increased ILC2 population in human and mouse stomach tissue, accompanied by elevated IL-5 production and B cell numbers [55,57]. Treatment of $H$. pylori-infected germ free (GF) mice with an anti-IL-5 neutralizing antibody significantly decreased the B cell population. ILC2-mediated B cell activation enhanced the IgA response against H. pylori and subsequently provided protection against the infection. Even though only a minor role in homeostasis 
regulation can be attributed to ILC2, they have recently been shown to be involved in the defense against several pathogens. ILC2-deficient mice suffered from exacerbated inflammation and gastric bleeding [55]. At present, increasing antibiotic resistance among $H$. pylori strains is causing problems in patients [58]. The new insights into $H$. pylori infection and the underlying mechanism of immunity may lead to better approaches for therapy.

\subsection{ILC3}

ILC3 has been understood as the most important cell type involved in the repulsion of bacterial infection as well as in the interaction with commensal microbiota. The interaction with commensal bacteria has been addressed by many groups; however, the exact role of ILC3 remains controversial. Whereas several studies showed a decreased number of ILC3 in GF mice [59,60], others did not observe a microbiota-mediated influence on the ILC3 population [61]. ILC3 sense various environmental signals including neuronal signals [62], as well as dietary and bacterial metabolites [63,64], which modulate ILC3 differentiation and function. Commensal bacteria periodically penetrate the mucosal barrier; thus, mechanisms have evolved to minimize inflammation and maintain physiological homeostasis. ILC3 has been reported to interact with commensal bacteria indirectly [65,66]. Interposed mononuclear phagocytes, such as CD11 $c^{+}$DC, respond to commensal bacteria via secretion of IL-23 and IL- $1 \beta$, which then induce IL-22 production by ILC3 [67]. ILC3-derived IL-22 is crucial for containing commensal bacterial dissemination through the induction of antimicrobial peptides such as $\operatorname{RegIII} \beta, \operatorname{RegIII} \gamma$, and peptides of the S100 family [68]. Depletion of ILCs leads to systemic inflammation [69]. IL-22 signaling further acts on intestinal epithelial cells by inducing fucosylation [70], thus maintaining the barrier integrity in the intestinal tract. It has been also reported that CCR6-expressing lymphoid tissue inducer (LTi)-like ILC3 express major histocompatibility complex class II (MHC class II) to downregulate commensal bacteria-specific $\mathrm{CD}^{+} \mathrm{T}$ cell responses, and thus to limit spontaneous inflammation [71].

\subsubsection{Citrobacter rodentium}

In the initial phase of $C$. rodentium infection, IL-22 expression by ILC3 is crucial for the immune defense [60,72], whereas clearance of the bacteria requires lymphocytes from the adaptive immune system [73]. Therefore, $\mathrm{CD} 4^{+}$cells are the main source of IL-22 in the late phase of infection [74,75]. Activation of ILC3 during $C$. rodentium infection is mediated by many pathways including specific activation of ILC3 surface receptors [59,76-84], diet- and bacteria-derived metabolites [85-91] and interposed phagocytes [92-96].

A recent study showed that knockout mice specifically lacking MHC class II on ILC3 had an increased Tfh cell response upon C. rodentium infection. This was accompanied by increased IgA levels as well as increased pathogen-specific IgA. Interestingly, the MHC class II depletion had no significant effect on the overall course of infection, indicating a crucial role of LTi-ILC3 in the orchestration of the IgA response [76]. In addition, ILC3 also express the NK cell receptor P1 (NKR-P1R), which is activated by C-type lectin-related type II transmembrane (Clr) proteins in the gut lamina propria. Loss of NKR-P1R leads to elevated numbers of ILC3, but increases susceptibility to C. rodentium due to impaired cell function [77].

The increased susceptibility to $C$. rodentium infection is also induced by disturbance of the gut microbiota, and thus dietary-derived metabolites presumably shape the immune system and further alter infection prognosis [97]. G-protein-coupled receptors (GPCR) are known as an important class of receptors for processing environmental cues. They are expressed on various immune cells and play an important role in cell recruitment and migration [97-99]. In recent years, the GPCR on ILC3 have been hypothesized to be involved in ILC3 regulation. Indeed, the GPC receptor GPR183 (also known as EBI2) is expressed on LTi-ILC3 cells. GPR183 activation by 7a,25-dihydroxycholesterol (7a,25-OHC), which is produced by stromal cells in lymphoid follicles, promotes ILC3 migration and is crucial for the formation of isolated lymphoid follicles and cryptopatches [78]. These findings were extended by another study, which demonstrated that ILC3 in the mesenteric lymph node (mLN) and lamina 
propria migrate towards the GPR183 ligand 7a,25-OHC in vitro. GPR183-mediated accumulation of ILC3 was thus crucial for optimal IL-22 production and protection against $C$. rodentium [79]. Another group additionally demonstrated the importance of the GPCR free fatty acid receptor 2 (Ffar2) in protection from bacterial infection [59]. Mice lacking Ffar2 showed exacerbated symptoms upon $C$. rodentium infection due to a decreased number of IL-22-producing ILC3 and an altered expression level of anti-bacterial peptides and mucus-associated proteins [59]. These reports indicate that various receptors, which are expressed on ILC 3 and induced by the trigger of $C$. rodentium exposure, are involved in the regulation of immune responses.

The aryl hydrocarbon receptor (Ahr) is a ligand-inducible transcription factor that is expressed on various cell types in the gastrointestinal tract. There, it responds to environmental toxins such as 2,3,7,8-tetrachloro-dibenzo-p-dioxin (TCDD) but also to endogenous ligands from the diet, microbiome or host cells $[80,100]$. However, it has been reported that Ahr is expressed on ILC3, where it plays an important role in protection from C. rodentium infection, as Ahr-deficient mice showed augmented infection symptoms [81-83]. Ahr is also involved in the regulation of Th17 cells via ILC3 [71,84], suggesting a link between nutrients and ILC3, mirroring adaptive Th17 cells in the gut.

Another dietary-sensing molecule is vitamin A, which is widely associated with intestinal homeostasis by promoting mucosal barrier integrity and immune cell recruitment [101,102]. Moreover, the vitamin A metabolite retinoic acid (RA) is involved in the regulation of ILC3 activity. RA directly regulates the transcription factor ROR $\gamma \mathrm{t}$ and further ensures the correct development of ILC3 [85]. Lack of RA resulted in a diminished population of ILC3 and enhanced susceptibility to C. rodentium infection $[86,87]$. Recently, it has been also shown that ILCs express the transcriptional repressor, hypermethylated in cancer 1 (HIC1, ZBTB29), which is regulated by vitamin A. Lack of HIC1 abolished IL-22-expressing ILC3 and increased susceptibility to C. rodentium infection [88]. In contrast to vitamin A, vitamin D has been shown to negatively regulate ILC3 in C. rodentium infection. Mice lacking the vitamin D receptor (VDR) had increased resistance to $C$. rodentium infection, accompanied by an augmented number of ILC3 as well as increased IL-22 and anti-bacterial peptide secretion [89]. Subsequent responses to vitamin D suppressed IL-22, IL-17A, and GM-CSF secretion [90]. Consistent with these mouse studies, IL-23 and IL-1 $\beta$ stimulation of human mucosal ILC3 resulted in upregulation of the VDR. However, in contrast to these studies, a protective role of vitamin D in C. rodentium infection has been recently reported [91]. Here, knockout mice for the vitamin D $1 \alpha$-hydroxylase (Cyp27B1), which converts vitamin D to the active VDR-binding form, developed a fatal C. rodentium infections course, characterized by reduced Citrobacter-specific antibody responses, diminished ILC 3 and concomitant IL-22 and IL-17 expression [91].

Besides diet metabolites, a myeloid-ILC3 crosstalk has been proposed to influence the immune response in bacterial infection. Depletion of the chemokine receptor CX3CR1 lead to decreased IL-22 production by ILC3 and disturbed C. rodentium defense [92]. Upon infection, CX3CR $1^{+}$DCs release the chemokine CXCL16, which activates ILC3 via CXCR6, thus stimulating IL-22 release and the expression of antimicrobial peptides (AMPs) $[93,94]$. Expression of the tumor necrosis factor (TNF) family member TL1A in macrophages has been further shown to enhance IL-22 production by ILC3 [94]. Recently, the recombination signal binding protein for immunoglobulin $\mathrm{JK}$ (RBP-J), originally called that because it bound to the recombination signal sequences (RSS) upstream of each JK gene segment [103], has also been identified to be crucial for $C$. rodentium clearance by promoting the secretion of IL-22 by ILC 3 via macrophages [95]. Moreover, studies on mice lacking $\beta 2$-integrins using $\mathrm{CD} 18^{-/-}$mice revealed that $\beta 2$-integrin expression on macrophages promotes ILC3-derived IL-22 expression via IL-1 $\beta$, and thus is important for C. rodentium infection [96].

\subsubsection{Clostridium difficile}

As mentioned above, C. difficile infection in Rag1-/- mice revealed upregulation of both ILC1- and ILC3-associated proteins [42]. Loss of ILC3 or ILC3-derived IL-22 modestly reduced the resistance to acute $C$. difficile infection. A more recent study reported that the immune response of ILC 3 during 
C. difficile infection can be enhanced by acetate, which is one of the short-chain fatty acids (SCFA) recognized by the cognate receptor, free fatty acid receptor 2 (Ffar2) [104]. Beyond the acetate-Ffar2 interaction, the enhanced expression of the IL-1 receptor on ILC3 boosts IL-22 secretion in response to IL-1 $\beta$, which is increased in neutrophils during $C$. difficile infection.

\subsubsection{Salmonella spp.}

Salmonella spp. are also major bacteria used for the functional analysis of ILC3 in mice. Many groups have found that ILC3-derived IL-22 is essential for protection against S. typhimurium infection [45,105]. ILC3 also induce epithelial fucosylation via Fut2 expression in an IL-22- and lymphotoxin-dependent manner. Fucosylated carbohydrate moieties on intestinal epithelial cells form part of the environmental niche for commensal bacteria $[70,106,107]$. Thus, increased fucosylation strengthens the defense against S. typhimurium and concurrent shaping of the microenvironment [70].

As described above, the vitamin A-derived metabolite retinoic acid (RA) from intestinal epithelial cells promotes innate immunity by maturation and proliferation of IL-22-producing ROR $\gamma \mathrm{t}^{+}$ ILC3 $[105,108]$. The retinol dehydrogenase $7(R d h 7)$ is the key enzyme for the vitamin A metabolism which catalyzes the conversion of retinol into RA [108]. Rdh7 is known to regulate IL-22 expression by direct binding to the il22 locus [63]. Rdh7-depleted mice showed a decreased number of NKp46 ${ }^{+}$ILC3 in the small intestine and diminished IL-22 expression, which in turn impeded the IL-22-dependent production of antimicrobial peptides such as RegIII $\gamma$, RegIII $\beta$, and calprotectin subunits, S100A8 and S100A9. S. typhimurium infection in Rdh7 knockout mice leads to significantly reduced pathogen load in the feces compared to control mice, revealing that RA promotes $S$. typhimurium colonization by shaping the microbial environment [109].

\subsubsection{Helicobacter spp.}

The non-gastric species Helicobacter apodemus (H. apodemus) and H. typhlonius mainly colonize the intestine and have been shown to induce $\mathrm{T}$ cell responses [110,111]. A recent study using immune-compromised $\operatorname{Rag} 1^{-/}$mice showed that Helicobacter spp. negatively regulated ROR $\gamma \mathrm{t}^{+}$ ILC3, especially T-bet ${ }^{+}$ILC3, and reduced their proliferative capacity. In contrast, wild type mice could sustain ILC3 function in the presence of Helicobacter spp., indicating an interaction between ILCs and effector T cells [112]. Hepworth and colleagues recently reported that ILC3 suppress the T cell-dependent IgA response to H. typhlonius in order to preserve the microbial niche [76]. Both studies revealed a mutual interaction of Helicobacter spp. and ILCs through a complex mechanism, which also involves adaptive $\mathrm{T}$ cell activation.

\section{Infections of the Lung}

The lung is a nonlymphoid organ, but also an organ at risk for infection due to its large exposure to antigens and pathogens, similar to the gastrointestinal tract. The lung exhibits an interconnected network of resident immune cells, thus many reports with a focus on lung immunity can be found currently. Initially, the important function of NK cells in the lung was discovered in both mouse and human [113,114]. In recent years, IL-33 produced by lung epithelium has been identified to be an important mediator of lung homeostasis. Immediate upregulation of IL-33 resulted in the recruitment of ILC2 and simultaneous appearance of alveolar macrophages [115]. It is generally understood that ILCs in the lung are mainly tissue-resident cells, which are strongly affected by changes in the local microenvironment.

\subsection{ILC1 and NK Cells}

\subsubsection{Pneumoniae}

Pneumonia remains one of the most common causes of death upon infection in developed countries [116]. Lung infections are frequently caused by the pathogens Streptococcus pneumoniae (S. 
pneumoniae), Klebsiella pneumoniae (K. pneumoniae), and Pseudomonas aeruginosa (P. aeruginosa). Innate lymphocyte-derived inflammatory responses including TNF, IL-23, IL-17, and IFN- $\gamma$ has been shown to be essential for the clearance of K. pneumoniae infection [117,118]. A mutual interaction between NK cells and macrophages play a critical role for bacteria containment. Macrophage-derived type I IFNs promote the production of IFN- $\gamma$ in NK cells, which in turn induces a feed-back loop to produce IL-12 in macrophages [119].

\subsubsection{Bordetella pertussis}

The Gram-negative bacterium Bordetella pertussis (B. pertussis) causes the severe respiratory infection pertussis, so called whooping cough. Despite a vaccine can prevent disease outbreak, it remains important to understand pathogenicity, as pertussis has resurged in the past years [120,121]. NK cells have been also shown to contribute to the clearance of B. pertussis, as disruption of IFN- $\gamma$ production in the mouse model exacerbated disease progression [122,123]. During infection, B. pertussis activates the NLRP3 inflammasome in human macrophages, which results in caspase-mediated IL-18 and IL-1 $\beta$ release [124]. IL-18-mediated NK cell activation promotes the secretion of proinflammatory cytokines such as IFN- $\gamma[125,126]$ and an enhanced proinflammatory response against the pathogen [124].

\subsection{ILC2}

\section{Pneumoniae}

By focusing on ILC2 in the lungs, some important functions have been described in a mouse model of Pneumoniae infection. IL-13 produced by ILC2 mediates the early polarization of alveolar macrophages into an IL-13-dependent anti-inflammatory M2 phenotype, which plays an important role in the maintenance of lung homeostasis. IL13 ${ }^{-/}$mice showed an accelerated immune response and increased bacterial clearance after infection with S. pneumoniae [115]. Taken together, ILC2 shape the alveolar macrophage phenotype by promoting a quiescent steady state immune environment, which, however, in turn delays the immune response to $S$. pneumoniae.

\subsection{ILC3}

\subsubsection{Pneumoniae}

Many studies have also described the importance of IL-22 and IL-17 produced by ILC3 as the key cytokines in bacterial-derived pneumonia [127-129]. Particularly, ILC3 rapidly accumulate in the lung, providing the only source of IL-22 during S. pneumoniae infection [130]. Upon infection, ILC3 are activated by DCs in a MyD88-dependent manner. Administration of the Toll-like receptor 5 agonist flagellin, which has been shown to activate ILCs and to stimulate cytokine production [131,132], enhanced IL-22 production by ILC3, leading to improved protection from S. pneumoniae infection [130]. Gray et al. demonstrated the importance of IL-22-producing ILC3 for resistance to pneumonia in neonates [133]. In their study, intestinal commensal bacteria were crucial for the $\mathrm{CD}_{103}{ }^{+} \mathrm{CD} 11 \mathrm{~b}^{+}$ DCs-dependent recruitment of IL-22-producing ILC3 into the lung in order to protect the mice from S. pneumoniae infection [133]. Thus, disruption of commensal bacteria impeded the migration of ILC3, leading to increased pathogen susceptibility. Susceptibility could be reversed by administration of exogenous IL-22 or ILC3 transfer. In contrast to the above mentioned studies, clearance of antibiotic-resistant clinical K. pneumoniae strains did not depend on IL-22 production [118]. Xiong et al. recently demonstrated the importance of ILC3 as a source of IL-17 in K. pneumoniae infection [118]. Here, they described a positive feed-back loop in which TNF-producing inflammatory monocytes were rapidly recruited to the lungs and increased IL-17-producing ILC3. This further enhanced monocyte-mediated bacterial uptake and elimination. Bacterial clearance was reduced in ILC-depleted Rag2-/- mice. Furthermore, IL-17 and IL-22 are crucial for prevention of chronic airway infection with $P$. aeruginosa, probably by orchestrating neutrophil recruitment $[134,135]$. 
Antibiotic resistance is a worldwide challenge for the treatment of bacterial pathogens and has led to the necessity for developing alternative medications. A recent study aimed to unravel the involved host factors responsible for carbapenem-resistant K. pneumoniae sequence type 258 (ST258) infection [136]. By using single cell RNA sequencing, the authors identified distinct clusters of IFN- $\gamma$-producing NK cells and $1117 \mathrm{a}^{+} \mathrm{Il}_{22}{ }^{+} \mathrm{ICOS}^{+} \mathrm{ILC} 3$ to be critical for the host resistance in this infection. However, these studies did not unequivocally demonstrate the involvement of ILC3.

\subsubsection{Mycobacterium Tuberculosis}

Tuberculosis is an infectious disease caused by Mycobacterium tuberculosis and is still the leading cause of death by a single infectious agent [137]. Immune deficient patients in particular show a severe course of disease, illustrating the importance of the innate and adaptive immune systems for disease protection [138].

Recently, a protective role of ILCs in M. tuberculosis infection has been demonstrated. During acute infection, the number of ILCs in the peripheral blood of patients was reduced and ILC1 and ILC3, but not ILC2, were restored after clearance of the infection. Despite of ILC depletion in the peripheral blood, studies using mouse models further revealed the accumulation of ILC3 in the lungs of infected mice. This is an essential action for the recruitment of alveolar macrophages and further containment of the infection. Conversely, depletion of ILC3 was associated with impaired immune control of $M$. tuberculosis as a result of reduced production of IL-17 and IL-22 [139].

The generation of functional lymphoid follicles is an essential mechanism in immune defense. The chemokine C-X-C motif chemokine ligand 13 (CXCL13)/C-X-C motif chemokine receptor 5 (CXCR5) interaction induces lymphocyte recruitment and generation of inducible bronchus-associated lymphoid tissues (iBALT) [140]. Both CXCL13 and CXCR5 were upregulated in lungs during M. tuberculosis infection $[139,140]$. This upregulation of CXCR5 on circulating ILCs reveals the importance of the CXCL13/CXCR5-axis for the migration of ILCs and further localization of ILC3 in protective lymphoid follicles within granulomas in the lung [139]. In summary, these studies demonstrate an important protective role of ILC3 in M. tuberculosis infection. Additional studies in animal models and data from human are needed to verify these hypotheses and to obtain more detailed insights into the role of ILCs in M. tuberculosis.

\section{Infections of the Skin}

\section{ILC2}

In addition to the mucosal surfaces, the skin is one of the largest organs harboring an enormous number of bacteria. ILC2 are the predominant ILC subgroup in the skin, where they contribute to maintenance of skin homeostasis [141]. Human studies of patients suffering from atopic dermatitis (AD) and studies in mice with experimental AD revealed increased numbers of ILC2 and amphiregulin expression in the lesional skin [17,142-144]. Atopic dermatitis is accompanied by an increased prevalence of Staphylococcus aureus [145]. Recently Hardman et al. showed that human skin ILC2 can express CD1 group 1 protein CD1a upon TSLP activation [146]. CD1a expressing ILC2 were able to sense $S$. aureus via presenting endogenous lipid antigens to CD1a-reactive T cells in a phospholipase 2 (PLA2G4A)-dependent way, eventually promoting skin inflammation [146].

\section{Systemic Consequences of Bacterial Infections-The Role of ILCs in Sepsis}

Sepsis and septic shock can be a severe consequence of a bacterial infection. Sepsis is newly defined as a dysregulated host-response to an infection, which leads to life-threatening organ dysfunction due to a lack of immune homeostasis $[147,148]$. The initial phase of sepsis is characterized by an augmented activation of the innate immune system leading to the "cytokine storm" and ending up in multiple organ failure $[149,150]$. ILCs mainly reside in tissues close to the mucosal barrier; however, they are also present in human peripheral blood [149]. Recently, still controversial results have been reported 
that describe the distribution of circulating ILC subsets in septic patients. Cruz-Zárate et al. reported a significant decrease in ILC1 and ILC3 in peripheral blood of such patients, which was related to the expression of an apoptotic marker on the ILC surface [151]. In contrast, Carvelli et al. did not detect a difference in total ILC cell numbers, but reported an increase in ILC1 and decrease in ILC3 in the peripheral blood of patients with septic shock [149]. They further hypothesized the possible importance of ILC plasticity and an ILC3-ILC1 shift as a reason for the changes in ILC numbers. The differences between these studies might be due to differences in the clinical study conditions, thus, more studies are needed to verify the role of circulating ILCs in sepsis.

Multiple organ failure is one of the main causes of mortality in sepsis. Recently, several groups have begun to examine the contribution of ILCs in secondary organs during sepsis. Chun et al. used a murine model of acute septic shock by cecal ligation and puncture to study the contribution of ILC2 in different organs [152]. The study revealed a rapid increase of ILC2 in the small intestine and peritoneal cavity and a decrease in the liver $24 \mathrm{~h}$ after the septic insult. This was accompanied with an increased concentration of IL-13 in the peritoneal fluid. Moreover, mice lacking IL-13-producing cells were shown to have a survival advantage, ameliorated tissue injury and reduced IL-10 concentration in peritoneal fluid [152]. The same sepsis mouse model provided evidence that the number of ILC2 increases in the lung. In fact, lung epithelial cells release increased amounts of IL-33 during sepsis, leading to the expansion of ILC2 via the ST2 receptor [153]. Further experiments revealed that the increased population of ILC2 secrete IL-9, which protects the lung epithelial cells from pyroptosis by attenuating caspase-1 activation [154]. These data suggest a tissue-protective mechanism by ILC2 that negatively regulates lung inflammation following sepsis. These studies demonstrate a complex contribution of ILCs in sepsis with potential organ site-specific effects.

\section{Discussion}

ILCs play an essential role in the maintenance of tissue homeostasis, which is regulated by various microorganisms, especially in tissues at mucosal surfaces (Figure 1). In recent years, many reports revealed the importance of ILCs for host defense mechanisms against bacterial infections, with intensive studies on ILCs in the gastrointestinal tract, as indicated in Table 1. ILC3 and ILC1 are well-known to be involved in the defense against pathogens. However, the latest reports further demonstrated that the ILC2 subset should not be neglected in studies of bacterial infections. Therefore, the currently available information reveals that an intricate network of all ILC subsets is involved in the repulsion of pathogens. Several studies using different bacterial infection models pointed out the specific roles of individual ILC subtypes or the simultaneous involvement of different subtypes. Moreover, cytokine release seems to be specific for the respective bacteria.

The capability of ILCs to change their transcription profiles, and thus undergo a switch within the subsets, makes it even more difficult to understand the complex molecular mechanisms involved in ILC responses. This underlines the importance of further studies to carefully perform ILC subset classification and the necessity for further studies to clarify plasticity promoting factors.

In the last decades, treatment of bacterial infections generally included the use of antibiotics, thereby forcing bacteria to evolve mechanisms to escape the treatment. Thus, antibiotic resistance is currently an increasing concern worldwide. As ILCs are involved in early bacterial defense mechanisms, they might represent a new target for supportive therapy. Similar challenges arise for the treatment of sepsis in the ICU, where a reliable therapy is still lacking. Therefore, the development of new treatment methods is urgently needed. Based on data from recent studies, ILCs might represent a promising target for such new treatment methods. Overall, additional studies are required to confirm and further unravel the detailed regulatory mechanisms of ILCs in bacterial infection and sepsis. Human studies are especially needed to provide a reliable basis for potential treatment development. 


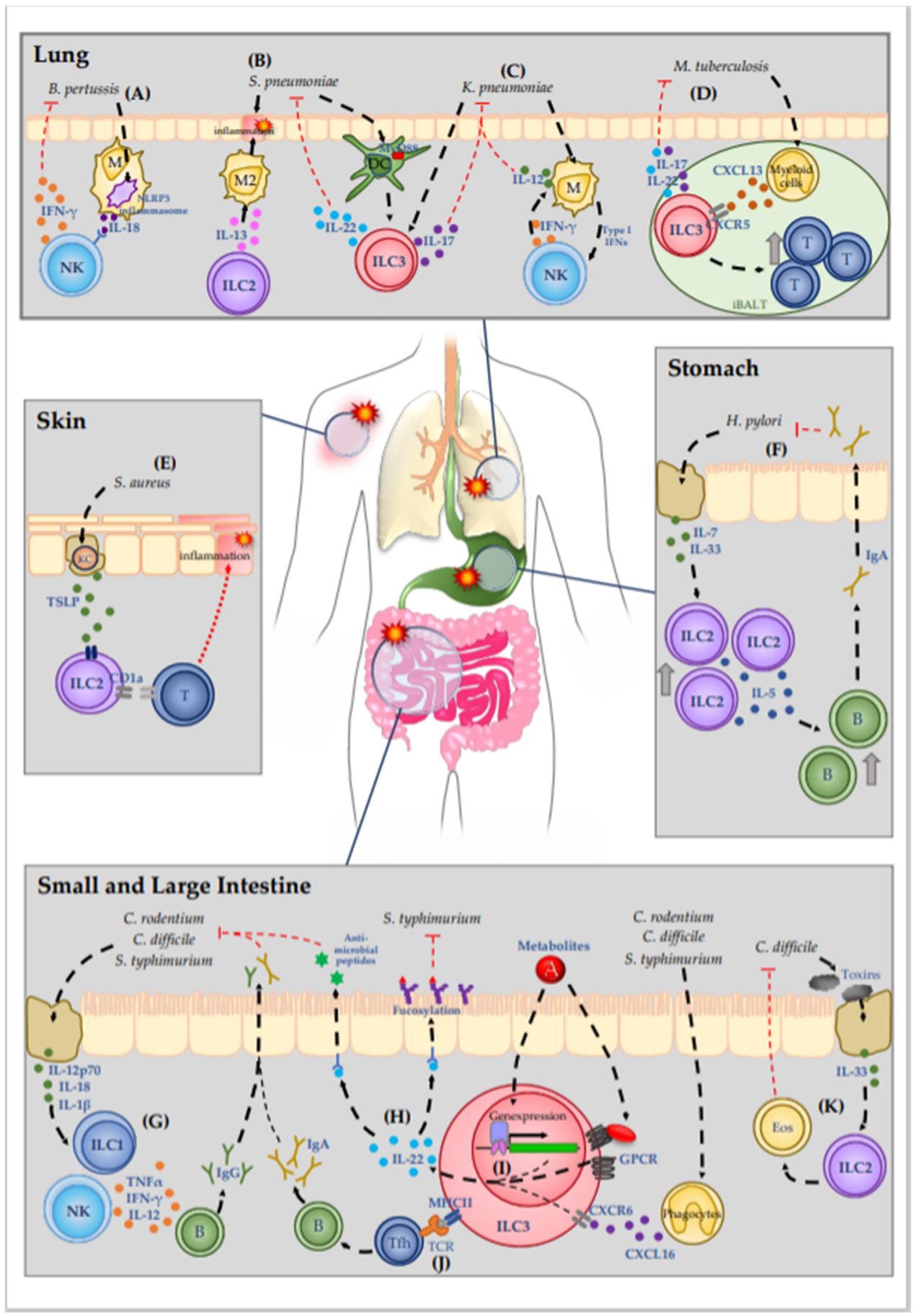

Figure 1. Molecular mechanisms of ILC-mediated immune defense against bacterial infections.Mucosal tissues are sites that are especially prone to bacterial infection due to the high prevalence of pathogenic bacteria. (A) B. pertussis causes the severe respiratory infection pertussis. Detection of B. pertussis by macrophages initiates IL-18 release via NLPR3 inflammasome activation, which promotes IFN- $\gamma$ release from NK cells. $(\mathbf{B}, \mathbf{C})$ In the lung pneumonia can be caused by the pathogens S. pneumoniae and K. pneumoniae. (B) ILC-2-drived IL-13 mediates early polarization of alveolar macrophages into the M2 phenotype. The quiescent immune environment delays the immune response against S. pneumoniae. $S$. pneumoniae is further detected by DC, which then activate ILC3 in a MyD88-dendent manner, resulting in the production of IL-22. (C) ILC3 are also activated during K. pneumoniae infection, increasing 
IL-17 expression. A mutual interaction of macrophages and NK cells results in IL-12 release from macrophages that plays a critical role in K. pneumoniae containment. (D) M. tuberculosis infection induces CXCL13 secretion by myeloid cells in the lymphoid tissue. CXCL13 activates ILC3 via CXCR5, inducing the secretion of IL-22 and IL-17. Moreover, activated ILC3 promotes lymphocyte recruitment to the iBALT site, thus inhibiting infection progression. (E) Patients with atopic dermatitis are susceptible for S. aureus infection. Lesional keratinocytes release TSLP, which increases CD1a expression on ILC2, which activates CD1a-reactive T cells and leads to the recruitment of further immune cells. (F) $H$. pylori infection in the stomach leads to epithelial cell damage, thus inducing release of IL-7 and IL-33. Enhanced cytokine secretion boosts ILC2 recruitment and activation and simultaneously enhances the expression of IL-5. IL-5 promotes the recruitment of B cells and concomitant production of IgA. In the stomach lumen, IgA neutralizes the pathogen, thus decreasing bacterial burden in the tissue. (G-K) In the intestinal tract, pathogens like C. rodentium, C. difficile, and S. typhimurium cause inflammation with various symptoms. (G) Damage to epithelial cells induces release of interleukins such as IL-12p70, IL-18 and IL-1 $\beta$, thus activating ILC1. ILC1-derived TNF- $\alpha$, IFN- $\gamma$, and IL-12 promote the generation of pathogen specific IgG. (H-J) The most well-studied ILC subgroup in terms of bacterial infections is ILC3. (H) Activated ILC3 mediate bacterial infection protection mainly via the secretion of IL-22, which initiates the secretion of antimicrobial peptides from epithelial cells as well as epithelial cell fucosylation, thus impeding bacterial colonization. (I) IL-22 expression by ILC3 can be induced by various stimuli: By metabolites, which derive from the gut lumen and activate GPCR receptors or directly modulate gene expression of IL-22 promoting genes, or by the activation of CXCR6 via phagocyte-derived CXCL16. (J) Moreover, MHC class II expression on ILC3 allows the direct presentation of pathogen-derived peptide antigens to $\mathrm{T}$ cells. promoting the generation of pathogen-specific IgA. (K) C. difficile-secreted toxins induce epithelial cell damage, resulting in IL-33 release. IL-33 activates ILC2, which promote the recruitment of eosinophils, thereby supporting the clearance of the pathogen and the healing of the epithelial layer. Abbreviations: DC—dendritic cells; M2—type 2 macrophages; T-T cells; KC—Keratinocytes; B-B cells; Eos—Eosinophils; GPCR—G-protein-coupled receptors.

Table 1. Participation of innate lymphoid cell (ILC) subgroups in bacterial infection defense. Abbreviations: MHCII-major histocompatibility complex class II; VitA—Vitamin A/retinol; RA—retinoic acid; GPCR—G-protein-coupled receptors.

\begin{tabular}{|c|c|c|c|c|c|c|}
\hline Organ & Bacteria & $\begin{array}{c}\text { ILC } \\
\text { Subgroup }\end{array}$ & Cytokines a & $\begin{array}{l}\text { volved Signaling } \\
\text { ways }\end{array}$ & $\begin{array}{l}\text { Effect on } \\
\text { Host }\end{array}$ & References \\
\hline \multirow{6}{*}{ Intestine } & \multirow{2}{*}{$\begin{array}{l}\text { Citrobacter } \\
\text { rodentium }\end{array}$} & ILC1 & $\begin{array}{l}\text { Activation: } \\
\text { Production: }\end{array}$ & $\begin{array}{c}? \\
\text { TNF- } \alpha, \text { IFN- } \gamma, \text { IL-12 }\end{array}$ & protective & {$[39,40]$} \\
\hline & & ILC3 & $\begin{array}{l}\text { Activation: } \\
\text { Production: }\end{array}$ & $\begin{array}{c}\text { MHCII; GPCR } \\
\text { (Ffar2, GPR183); } \\
\text { Ahr; VitA/RA; } \\
\text { CXCL16/CXCR6 } \\
\text { IL-22 }\end{array}$ & protective & $\begin{array}{c}{[60,61,72,73,77-80} \\
\quad 82-91,93-97]\end{array}$ \\
\hline & \multirow{3}{*}{$\begin{array}{l}\text { Clostridium } \\
\text { difficile }\end{array}$} & ILC1 & $\begin{array}{l}\text { Activation: } \\
\text { Production: }\end{array}$ & $\begin{array}{c}? \\
\text { IFN- } \gamma\end{array}$ & protective & [43] \\
\hline & & ILC2 & $\begin{array}{l}\text { Activation: } \\
\text { Production: }\end{array}$ & $\begin{array}{c}\text { IL-33 } \\
?\end{array}$ & protective & [57] \\
\hline & & ILC3 & $\begin{array}{l}\text { Activation: } \\
\text { Production: }\end{array}$ & $\begin{array}{l}\text { IL-1 } \beta \\
\text { IL-22 }\end{array}$ & protective & {$[43,105]$} \\
\hline & $\begin{array}{l}\text { Salmonella } \\
\text { typhimurium }\end{array}$ & ILC3 & $\begin{array}{l}\text { Inhibition: } \\
\text { Activation: } \\
\text { Production: }\end{array}$ & $\begin{array}{c}\text { VitA/RA } \\
? \\
\text { IL-22 }\end{array}$ & $\begin{array}{l}\text { harmful } \\
\text { protective }\end{array}$ & {$[71,88,106-108,110]$} \\
\hline
\end{tabular}


Table 1. Cont.

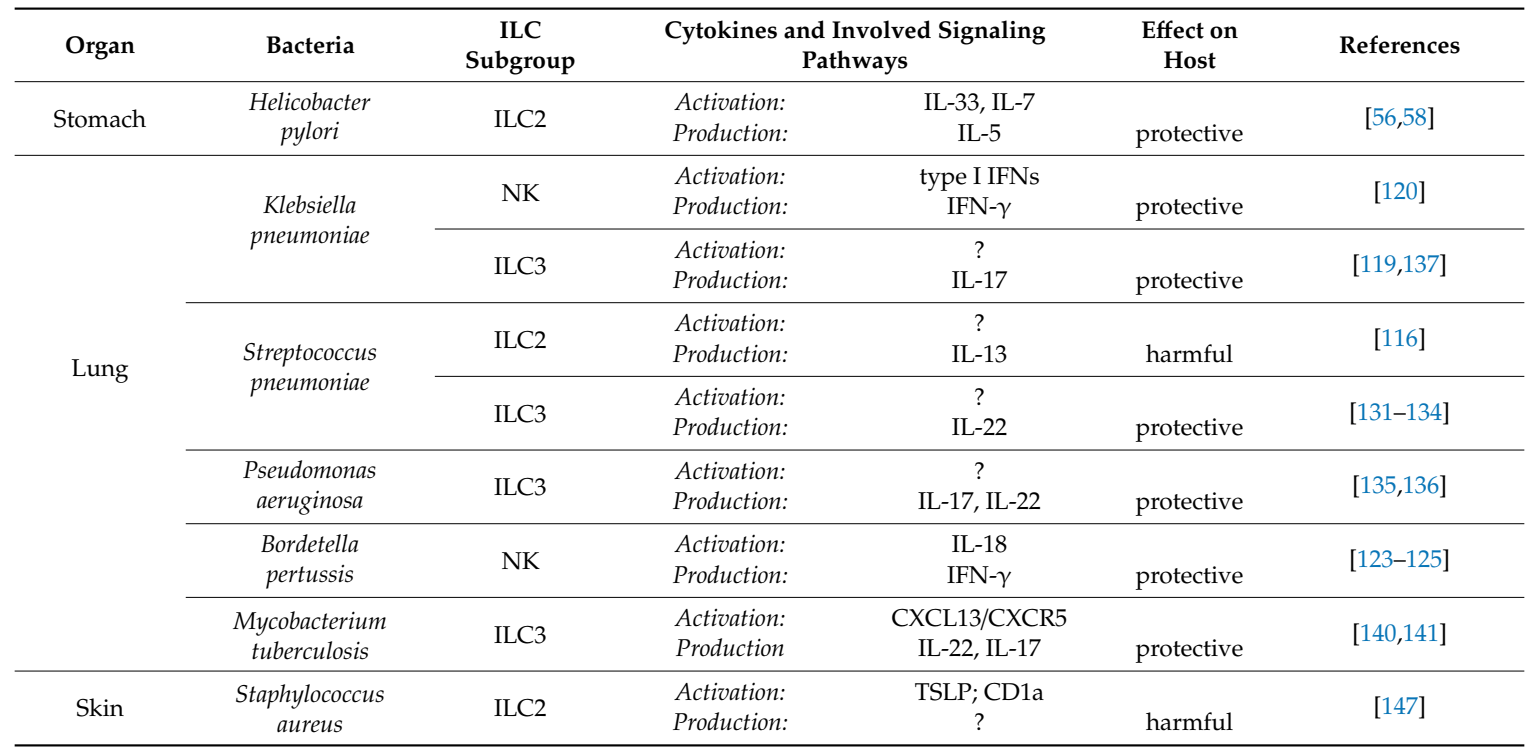

Author Contributions: K.B. and N.S.-T. wrote the manuscript, and H.O. provided critical comments. All authors have read and agreed to the published version of the manuscript.

Funding: K.B. was supported by Deutsche Forschungsgemeinschaft (DFG; BE 6909/1-1). N.S.-T. was supported by the Japan Society for the Promotion of Science KAKENHI (18K07189) and Yakult Bio-Science foundation. H.O. was supported by the Japan Society for the Promotion of Science KAKENHI (16H05207), Japan Agency for Medical Research and Development-Core Research for Evolutional Science and Technology (JP18gm0710009).

Acknowledgments: We gratefully thank Peter D. Burrows for his critical comments and proof reading of the manuscript.

Conflicts of Interest: The authors declare no conflict of interest.

\section{References}

1. Vivier, E.; Artis, D.; Colonna, M.; Diefenbach, A.; Di Santo, J.P.; Eberl, G.; Koyasu, S.; Locksley, R.M.; McKenzie, A.N.J.; Mebius, R.E.; et al. Innate Lymphoid Cells: 10 Years On. Cell 2018, 174, 1054-1066. [CrossRef] [PubMed]

2. Spits, H.; Artis, D.; Colonna, M.; Diefenbach, A.; Di Santo, J.P.; Eberl, G.; Koyasu, S.; Locksley, R.M.; McKenzie, A.N.J.; Mebius, R.E.; et al. Innate lymphoid cells-A proposal for uniform nomenclature. Nat. Rev. Immunol. 2013, 13, 145-149. [CrossRef] [PubMed]

3. Constantinides, M.G.; McDonald, B.D.; Verhoef, P.A.; Bendelac, A. A committed precursor to innate lymphoid cells. Nature 2014, 508, 397-401. [CrossRef] [PubMed]

4. Ishizuka, I.E.; Constantinides, M.G.; Gudjonson, H.; Bendelac, A. The Innate Lymphoid Cell Precursor. Annu. Rev. Immunol. 2016, 34, 299-316. [CrossRef]

5. Gordon, S.M.; Chaix, J.; Rupp, L.J.; Wu, J.; Madera, S.; Sun, J.C.; Lindsten, T.; Reiner, S.L. The transcription factors T-bet and Eomes control key checkpoints of natural killer cell maturation. Immunity 2012, 36, 55-67. [CrossRef]

6. Moro, K.; Yamada, T.; Tanabe, M.; Takeuchi, T.; Ikawa, T.; Kawamoto, H.; Furusawa, J.-I.; Ohtani, M.; Fujii, H.; Koyasu, S. Innate production of $\mathrm{T}(\mathrm{H}) 2$ cytokines by adipose tissue-associated c-Kit ${ }^{+} \mathrm{Sca}-1^{+}$lymphoid cells. Nature 2010, 463, 540-544. [CrossRef]

7. Price, A.E.; Liang, H.-E.; Sullivan, B.M.; Reinhardt, R.L.; Eisley, C.J.; Erle, D.J.; Locksley, R.M. Systemically dispersed innate IL-13-expressing cells in type 2 immunity. Proc. Natl. Acad. Sci. USA 2010, 107, 11489-11494. [CrossRef]

8. Neill, D.R.; Wong, S.H.; Bellosi, A.; Flynn, R.J.; Daly, M.; Langford, T.K.A.; Bucks, C.; Kane, C.M.; Fallon, P.G.; Pannell, R.; et al. Nuocytes represent a new innate effector leukocyte that mediates type-2 immunity. Nature 2010, 464, 1367-1370. [CrossRef] 
9. Hoyler, T.; Klose, C.S.N.; Souabni, A.; Turqueti-Neves, A.; Pfeifer, D.; Rawlins, E.L.; Voehringer, D.; Busslinger, M.; Diefenbach, A. The transcription factor GATA-3 controls cell fate and maintenance of type 2 innate lymphoid cells. Immunity 2012, 37, 634-648. [CrossRef]

10. Mjösberg, J.; Bernink, J.; Golebski, K.; Karrich, J.J.; Peters, C.P.; Blom, B.; te Velde, A.A.; Fokkens, W.J.; van Drunen, C.M.; Spits, H. The transcription factor GATA3 is essential for the function of human type 2 innate lymphoid cells. Immunity 2012, 37, 649-659. [CrossRef]

11. Klein Wolterink, R.G.J.; Serafini, N.; van Nimwegen, M.; Vosshenrich, C.A.J.; de Bruijn, M.J.W.; Fonseca Pereira, D.; Veiga Fernandes, H.; Hendriks, R.W.; Di Santo, J.P. Essential, dose-dependent role for the transcription factor Gata3 in the development of IL-5 $5^{+}$and IL-13 ${ }^{+}$type 2 innate lymphoid cells. Proc. Natl. Acad. Sci. USA 2013, 110, 10240-10245. [CrossRef] [PubMed]

12. Fallon, P.G.; Ballantyne, S.J.; Mangan, N.E.; Barlow, J.L.; Dasvarma, A.; Hewett, D.R.; McIlgorm, A.; Jolin, H.E.; McKenzie, A.N.J. Identification of an interleukin (IL)-25-dependent cell population that provides IL-4, IL-5, and IL-13 at the onset of helminth expulsion. J. Exp. Med. 2006, 203, 1105-1116. [CrossRef] [PubMed]

13. Smith, K.A.; Löser, S.; Varyani, F.; Harcus, Y.; McSorley, H.J.; McKenzie, A.N.; Maizels, R.M. Concerted IL-25R and IL-4R $\alpha$ signaling drive innate type 2 effector immunity for optimal helminth expulsion. eLife 2018, 7. [CrossRef] [PubMed]

14. Bouchery, T.; Kyle, R.; Camberis, M.; Shepherd, A.; Filbey, K.; Smith, A.; Harvie, M.; Painter, G.; Johnston, K.; Ferguson, P.; et al. ILC2s and T cells cooperate to ensure maintenance of M2 macrophages for lung immunity against hookworms. Nat. Commun. 2015, 6, 6970. [CrossRef] [PubMed]

15. Tojima, I.; Matsumoto, K.; Kikuoka, H.; Hara, S.; Yamamoto, S.; Shimizu, S.; Kouzaki, H.; Shimizu, T. Evidence for the induction of Th2 inflammation by group 2 innate lymphoid cells in response to prostaglandin D2 and cysteinyl leukotrienes in allergic rhinitis. Allergy 2019, 74, 2417-2426. [CrossRef]

16. Kim, B.S.; Siracusa, M.C.; Saenz, S.A.; Noti, M.; Monticelli, L.A.; Sonnenberg, G.F.; Hepworth, M.R.; Van Voorhees, A.S.; Comeau, M.R.; Artis, D. TSLP elicits IL-33-independent innate lymphoid cell responses to promote skin inflammation. Sci. Transl. Med. 2013, 5, 170ra16. [CrossRef]

17. Rak, G.D.; Osborne, L.C.; Siracusa, M.C.; Kim, B.S.; Wang, K.; Bayat, A.; Artis, D.; Volk, S.W. IL-33-Dependent Group 2 Innate Lymphoid Cells Promote Cutaneous Wound Healing. J. Investig. Dermatol. 2016, 136, 487-496. [CrossRef]

18. Akdis, C.A.; Arkwright, P.D.; Brüggen, M.-C.; Busse, W.; Gadina, M.; Guttman-Yassky, E.; Kabashima, K.; Mitamura, Y.; Vian, L.; Wu, J.; et al. Type 2 immunity in the skin and lungs. Allergy 2020. [CrossRef]

19. Klose, C.S.N.; Artis, D. Innate lymphoid cells control signaling circuits to regulate tissue-specific immunity. Cell Res. 2020, 30, 475-491. [CrossRef]

20. Eberl, G.; Marmon, S.; Sunshine, M.-J.; Rennert, P.D.; Choi, Y.; Littman, D.R. An essential function for the nuclear receptor RORgamma(t) in the generation of fetal lymphoid tissue inducer cells. Nat. Immunol. 2004, 5, 64-73. [CrossRef]

21. Cupedo, T.; Crellin, N.K.; Papazian, N.; Rombouts, E.J.; Weijer, K.; Grogan, J.L.; Fibbe, W.E.; Cornelissen, J.J.; Spits, H. Human fetal lymphoid tissue-inducer cells are interleukin 17-producing precursors to RORC+ CD127+ natural killer-like cells. Nat. Immunol. 2009, 10, 66-74. [CrossRef] [PubMed]

22. Klose, C.S.N.; Kiss, E.A.; Schwierzeck, V.; Ebert, K.; Hoyler, T.; d'Hargues, Y.; Göppert, N.; Croxford, A.L.; Waisman, A.; Tanriver, Y.; et al. A T-bet gradient controls the fate and function of CCR6-ROR $\gamma \mathrm{t}^{+}$innate lymphoid cells. Nature 2013, 494, 261-265. [CrossRef] [PubMed]

23. Verrier, T.; Satoh-Takayama, N.; Serafini, N.; Marie, S.; Di Santo, J.P.; Vosshenrich, C.A.J. Phenotypic and Functional Plasticity of Murine Intestinal NKp46 ${ }^{+}$Group 3 Innate Lymphoid Cells. J. Immunol. 2016, 196, 4731-4738. [CrossRef]

24. Belz, G.T. ILC2s masquerade as ILC1s to drive chronic disease. Nat. Immunol. 2016, 17, 611-612. [CrossRef] [PubMed]

25. Bal, S.M.; Golebski, K.; Spits, H. Plasticity of innate lymphoid cell subsets. Nat. Rev. Immunol. 2020. [CrossRef] [PubMed]

26. Vonarbourg, C.; Mortha, A.; Bui, V.L.; Hernandez, P.P.; Kiss, E.A.; Hoyler, T.; Flach, M.; Bengsch, B.; Thimme, R.; Hölscher, C.; et al. Regulated expression of nuclear receptor ROR $\gamma t$ confers distinct functional fates to NK cell receptor-expressing ROR $\gamma \mathrm{t}^{+}$innate lymphocytes. Immunity 2010, 33, 736-751. [CrossRef] [PubMed] 
27. Rankin, L.C.; Groom, J.R.; Chopin, M.; Herold, M.J.; Walker, J.A.; Mielke, L.A.; McKenzie, A.N.J.; Carotta, S.; Nutt, S.L.; Belz, G.T. The transcription factor T-bet is essential for the development of NKp46 ${ }^{+}$innate lymphocytes via the Notch pathway. Nat. Immunol. 2013, 14, 389-395. [CrossRef]

28. Ohne, Y.; Silver, J.S.; Thompson-Snipes, L.; Collet, M.A.; Blanck, J.P.; Cantarel, B.L.; Copenhaver, A.M.; Humbles, A.A.; Liu, Y.-J. IL-1 is a critical regulator of group 2 innate lymphoid cell function and plasticity. Nat. Immunol. 2016, 17, 646-655. [CrossRef]

29. Silver, J.S.; Kearley, J.; Copenhaver, A.M.; Sanden, C.; Mori, M.; Yu, L.; Pritchard, G.H.; Berlin, A.A.; Hunter, C.A.; Bowler, R.; et al. Inflammatory triggers associated with exacerbations of COPD orchestrate plasticity of group 2 innate lymphoid cells in the lungs. Nat. Immunol. 2016, 17, 626-635. [CrossRef] [PubMed]

30. Bal, S.M.; Bernink, J.H.; Nagasawa, M.; Groot, J.; Shikhagaie, M.M.; Golebski, K.; van Drunen, C.M.; Lutter, R.; Jonkers, R.E.; Hombrink, P.; et al. IL-1 $\beta$, IL-4 and IL-12 control the fate of group 2 innate lymphoid cells in human airway inflammation in the lungs. Nat. Immunol. 2016, 17, 636-645. [CrossRef]

31. Almeida, F.F.; Belz, G.T. Innate lymphoid cells: Models of plasticity for immune homeostasis and rapid responsiveness in protection. Mucosal Immunol. 2016, 9, 1103-1112. [CrossRef]

32. Kim, C.H.; Hashimoto-Hill, S.; Kim, M. Migration and Tissue Tropism of Innate Lymphoid Cells. Trends Immunol. 2016, 37, 68-79. [CrossRef] [PubMed]

33. Yudanin, N.A.; Schmitz, F.; Flamar, A.-L.; Thome, J.J.C.; Tait Wojno, E.; Moeller, J.B.; Schirmer, M.; Latorre, I.J.; Xavier, R.J.; Farber, D.L.; et al. Spatial and Temporal Mapping of Human Innate Lymphoid Cells Reveals Elements of Tissue Specificity. Immunity 2019, 50, 505-519.e4. [CrossRef] [PubMed]

34. Simoni, Y.; Fehlings, M.; Kløverpris, H.N.; McGovern, N.; Koo, S.-L.; Loh, C.Y.; Lim, S.; Kurioka, A.; Fergusson, J.R.; Tang, C.-L.; et al. Human Innate Lymphoid Cell Subsets Possess Tissue-Type Based Heterogeneity in Phenotype and Frequency. Immunity 2017, 46, 148-161. [CrossRef] [PubMed]

35. Castleman, M.J.; Dillon, S.M.; Purba, C.; Cogswell, A.C.; McCarter, M.; Barker, E.; Wilson, C. Enteric bacteria induce IFN $\gamma$ and Granzyme B from human colonic Group 1 Innate Lymphoid Cells. Gut Microbes 2019, 1-17. [CrossRef]

36. Clark, E.; Hoare, C.; Tanianis-Hughes, J.; Carlson, G.L.; Warhurst, G. Interferon gamma induces translocation of commensal Escherichia coli across gut epithelial cells via a lipid raft-mediated process. Gastroenterology 2005, 128, 1258-1267. [CrossRef] [PubMed]

37. Mullineaux-Sanders, C.; Sanchez-Garrido, J.; Hopkins, E.G.D.; Shenoy, A.R.; Barry, R.; Frankel, G. Citrobacter rodentium-host-microbiota interactions: Immunity, bioenergetics and metabolism. Nat. Rev. Microbiol. 2019, 17, 701-715. [CrossRef]

38. Reid-Yu, S.A.; Small, C.-L.N.; Coombes, B.K. CD3 ${ }^{-}$NK1.1 $1^{+}$cells aid in the early induction of a Th1 response to an attaching and effacing enteric pathogen. Eur. J. Immunol. 2013, 43, 2638-2649. [CrossRef]

39. Sepahi, A.; Liu, Q.; Friesen, L.; Kim, C.H. Dietary fiber metabolites regulate innate lymphoid cell responses. Mucosal Immunol. 2020. [CrossRef]

40. Saleh, M.M.; Petri, W.A. Type 3 Immunity during Clostridioides difficile Infection: Too Much of a Good Thing? Infect. Immun. 2019, 88, e00306-19. [CrossRef]

41. Poutanen, S.M.; Simor, A.E. Clostridium difficile-associated diarrhea in adults. CMAJ Can. Med. Assoc. J. 2004, 171, 51-58. [CrossRef] [PubMed]

42. Abt, M.C.; Lewis, B.B.; Caballero, S.; Xiong, H.; Carter, R.A.; Sušac, B.; Ling, L.; Leiner, I.; Pamer, E.G. Innate Immune Defenses Mediated by Two ILC Subsets Are Critical for Protection against Acute Clostridium difficile Infection. Cell Host Microbe 2015, 18, 27-37. [CrossRef] [PubMed]

43. Barthel, M.; Hapfelmeier, S.; Quintanilla-Martínez, L.; Kremer, M.; Rohde, M.; Hogardt, M.; Pfeffer, K.; Rüssmann, H.; Hardt, W.-D. Pretreatment of mice with streptomycin provides a Salmonella enterica serovar Typhimurium colitis model that allows analysis of both pathogen and host. Infect. Immun. 2003, 71, 2839-2858. [CrossRef] [PubMed]

44. Bao, S.; Beagley, K.W.; France, M.P.; Shen, J.; Husband, A.J. Interferon- $\gamma$ plays a critical role in intestinal immunity against Salmonella typhimurium infection. Immunology 2000, 99, 464-472. [CrossRef]

45. Godinez, I.; Haneda, T.; Raffatellu, M.; George, M.D.; Paixão, T.A.; Rolán, H.G.; Santos, R.L.; Dandekar, S.; Tsolis, R.M.; Bäumler, A.J. T Cells Help to Amplify Inflammatory Responses Induced by Salmonella enterica Serotype Typhimurium in the Intestinal Mucosa. Infect. Immun. 2008, 76, 2008-2017. [CrossRef] 
46. Songhet, P.; Barthel, M.; Stecher, B.; Müller, A.J.; Kremer, M.; Hansson, G.C.; Hardt, W.-D. Stromal IFN- $\gamma$ R-Signaling Modulates Goblet Cell Function During Salmonella Typhimurium Infection. PLoS ONE 2011, 6. [CrossRef]

47. Kupz, A.; Scott, T.A.; Belz, G.T.; Andrews, D.M.; Greyer, M.; Lew, A.M.; Brooks, A.G.; Smyth, M.J.; Curtiss, R.; Bedoui, S.; et al. Contribution of Thy $1^{+} \mathrm{NK}$ cells to protective IFN- $\gamma$ production during Salmonella typhimurium infections. Proc. Natl. Acad. Sci. USA 2013, 110, 2252-2257. [CrossRef]

48. Müller, A.; Solnick, J.V. Inflammation, immunity, and vaccine development for Helicobacter pylori. Helicobacter 2011, 16 (Suppl. S1), 26-32. [CrossRef]

49. Kang, J.; Blaser, M.J. Bacterial populations as perfect gases: Genomic integrity and diversification tensions in Helicobacter pylori. Nat. Rev. Microbiol. 2006, 4, 826-836. [CrossRef]

50. Ikuse, T.; Blanchard, T.G.; Czinn, S.J. Inflammation, Immunity, and Vaccine Development for the Gastric Pathogen Helicobacter pylori. Curr. Top. Microbiol. Immunol. 2019, 421, 1-19. [CrossRef]

51. Kondo, M.; Tamaoki, J.; Takeyama, K.; Nakata, J.; Nagai, A. Interleukin-13 induces goblet cell differentiation in primary cell culture from Guinea pig tracheal epithelium. Am. J. Respir. Cell Mol. Biol. 2002, 27, 536-541. [CrossRef] [PubMed]

52. Tukler Henriksson, J.; Coursey, T.G.; Corry, D.B.; De Paiva, C.S.; Pflugfelder, S.C. IL-13 Stimulates Proliferation and Expression of Mucin and Immunomodulatory Genes in Cultured Conjunctival Goblet Cells. Investig. Ophthalmol. Vis. Sci. 2015, 56, 4186-4197. [CrossRef] [PubMed]

53. Mosconi, I.; Geuking, M.B.; Zaiss, M.M.; Massacand, J.C.; Aschwanden, C.; Kwong Chung, C.K.C.; McCoy, K.D.; Harris, N.L. Intestinal bacteria induce TSLP to promote mutualistic T-cell responses. Mucosal Immunol. 2013, 6, 1157-1167. [CrossRef] [PubMed]

54. Maggi, L.; Montaini, G.; Mazzoni, A.; Rossettini, B.; Capone, M.; Rossi, M.C.; Santarlasci, V.; Liotta, F.; Rossi, O.; Gallo, O.; et al. Human circulating group 2 innate lymphoid cells can express CD154 and promote IgE production. J. Allergy Clin. Immunol. 2017, 139, 964-976.e4. [CrossRef]

55. Satoh-Takayama, N.; Kato, T.; Motomura, Y.; Kageyama, T.; Taguchi-Atarashi, N.; Kinoshita-Daitoku, R.; Kuroda, E.; Di Santo, J.P.; Mimuro, H.; Moro, K.; et al. Bacteria-Induced Group 2 Innate Lymphoid Cells in the Stomach Provide Immune Protection through Induction of IgA. Immunity 2020, 52, 635-649.e4. [CrossRef] [PubMed]

56. Frisbee, A.L.; Saleh, M.M.; Young, M.K.; Leslie, J.L.; Simpson, M.E.; Abhyankar, M.M.; Cowardin, C.A.; Ma, J.Z.; Pramoonjago, P.; Turner, S.D.; et al. IL-33 drives group 2 innate lymphoid cell-mediated protection during Clostridium difficile infection. Nat. Commun. 2019, 10, 2712. [CrossRef]

57. Li, R.; Jiang, X.-X.; Zhang, L.-F.; Liu, X.-M.; Hu, T.-Z.; Xia, X.-J.; Li, M.; Xu, C.-X. Group 2 Innate Lymphoid Cells Are Involved in Skewed Type 2 Immunity of Gastric Diseases Induced by Helicobacter pylori Infection. Mediat. Inflamm. 2017, 2017, 4927964. [CrossRef]

58. Rizvanov, A.A.; Haertlé, T.; Bogomolnaya, L.; Talebi Bezmin Abadi, A. Helicobacter pylori and Its Antibiotic Heteroresistance: A Neglected Issue in Published Guidelines. Front. Microbiol. 2019, 10, 1796. [CrossRef]

59. Chun, E.; Lavoie, S.; Fonseca-Pereira, D.; Bae, S.; Michaud, M.; Hoveyda, H.R.; Fraser, G.L.; Gallini Comeau, C.A.; Glickman, J.N.; Fuller, M.H.; et al. Metabolite-Sensing Receptor Ffar2 Regulates Colonic Group 3 Innate Lymphoid Cells and Gut Immunity. Immunity 2019, 51, 871-884.e6. [CrossRef]

60. Satoh-Takayama, N.; Vosshenrich, C.A.J.; Lesjean-Pottier, S.; Sawa, S.; Lochner, M.; Rattis, F.; Mention, J.-J.; Thiam, K.; Cerf-Bensussan, N.; Mandelboim, O.; et al. Microbial flora drives interleukin 22 production in intestinal $\mathrm{NKp}^{+} 6^{+}$cells that provide innate mucosal immune defense. Immunity 2008, 29, 958-970. [CrossRef]

61. Sawa, S.; Lochner, M.; Satoh-Takayama, N.; Dulauroy, S.; Bérard, M.; Kleinschek, M.; Cua, D.; Di Santo, J.P.; Eberl, G. ROR $\gamma \mathrm{t}^{+}$innate lymphoid cells regulate intestinal homeostasis by integrating negative signals from the symbiotic microbiota. Nat. Immunol. 2011, 12, 320-326. [CrossRef]

62. Jakob, M.O.; Murugan, S.; Klose, C.S.N. Neuro-Immune Circuits Regulate Immune Responses in Tissues and Organ Homeostasis. Front. Immunol. 2020, 11. [CrossRef] [PubMed]

63. Mielke, L.A.; Jones, S.A.; Raverdeau, M.; Higgs, R.; Stefanska, A.; Groom, J.R.; Misiak, A.; Dungan, L.S.; Sutton, C.E.; Streubel, G.; et al. Retinoic acid expression associates with enhanced IL-22 production by $\gamma \delta \mathrm{T}$ cells and innate lymphoid cells and attenuation of intestinal inflammation. J. Exp. Med. 2013, 210, 1117-1124. [CrossRef] [PubMed]

64. Qiu, J.; Heller, J.J.; Guo, X.; Chen, Z.E.; Fish, K.; Fu, Y.-X.; Zhou, L. The Aryl Hydrocarbon Receptor Regulates Gut Immunity through Modulation of Innate Lymphoid Cells. Immunity 2012, 36, 92-104. [CrossRef] 
65. Mortha, A.; Chudnovskiy, A.; Hashimoto, D.; Bogunovic, M.; Spencer, S.P.; Belkaid, Y.; Merad, M. Microbiota-Dependent Crosstalk Between Macrophages and ILC3 Promotes Intestinal Homeostasis. Science 2014, 343, 1249288. [CrossRef]

66. Gury-BenAri, M.; Thaiss, C.A.; Serafini, N.; Winter, D.R.; Giladi, A.; Lara-Astiaso, D.; Levy, M.; Salame, T.M.; Weiner, A.; David, E.; et al. The Spectrum and Regulatory Landscape of Intestinal Innate Lymphoid Cells Are Shaped by the Microbiome. Cell 2016, 166, 1231-1246.e13. [CrossRef]

67. Castleman, M.J.; Dillon, S.M.; Purba, C.M.; Cogswell, A.C.; Kibbie, J.J.; McCarter, M.D.; Santiago, M.L.; Barker, E.; Wilson, C.C. Commensal and Pathogenic Bacteria Indirectly Induce IL-22 but Not IFN $\gamma$ Production From Human Colonic ILC3s via Multiple Mechanisms. Front. Immunol. 2019, 10, 649. [CrossRef] [PubMed]

68. Sonnenberg, G.F.; Fouser, L.A.; Artis, D. Border patrol: Regulation of immunity, inflammation and tissue homeostasis at barrier surfaces by IL-22. Nat. Immunol. 2011, 12, 383-390. [CrossRef]

69. Sonnenberg, G.F.; Monticelli, L.A.; Alenghat, T.; Fung, T.C.; Hutnick, N.A.; Kunisawa, J.; Shibata, N.; Grunberg, S.; Sinha, R.; Zahm, A.M.; et al. Innate lymphoid cells promote anatomical containment of lymphoid-resident commensal bacteria. Science 2012, 336, 1321-1325. [CrossRef]

70. Goto, Y.; Obata, T.; Kunisawa, J.; Sato, S.; Ivanov, I.I.; Lamichhane, A.; Takeyama, N.; Kamioka, M.; Sakamoto, M.; Matsuki, T.; et al. Innate lymphoid cells regulate intestinal epithelial cell glycosylation. Science 2014, 345, 1254009. [CrossRef]

71. Hepworth, M.R.; Monticelli, L.A.; Fung, T.C.; Ziegler, C.G.K.; Grunberg, S.; Sinha, R.; Mantegazza, A.R.; Ma, H.-L.; Crawford, A.; Angelosanto, J.M.; et al. Innate lymphoid cells regulate CD4 ${ }^{+}$T-cell responses to intestinal commensal bacteria. Nature 2013, 498, 113-117. [CrossRef] [PubMed]

72. Zheng, Y.; Valdez, P.A.; Danilenko, D.M.; Hu, Y.; Sa, S.M.; Gong, Q.; Abbas, A.R.; Modrusan, Z.; Ghilardi, N.; de Sauvage, F.J.; et al. Interleukin-22 mediates early host defense against attaching and effacing bacterial pathogens. Nat. Med. 2008, 14, 282-289. [CrossRef] [PubMed]

73. Simmons, C.P.; Clare, S.; Ghaem-Maghami, M.; Uren, T.K.; Rankin, J.; Huett, A.; Goldin, R.; Lewis, D.J.; MacDonald, T.T.; Strugnell, R.A.; et al. Central role for B lymphocytes and CD4 ${ }^{+} \mathrm{T}$ cells in immunity to infection by the attaching and effacing pathogen Citrobacter rodentium. Infect. Immun. 2003, 71, 5077-5086. [CrossRef] [PubMed]

74. Bishu, S.; Hou, G.; El Zaatari, M.; Bishu, S.R.; Popke, D.; Zhang, M.; Grasberger, H.; Zou, W.; Stidham, R.W.; Higgins, P.D.R.; et al. Citrobacter rodentium Induces Tissue-Resident Memory CD4 ${ }^{+} \mathrm{T}$ Cells. Infect. Immun. 2019, 87. [CrossRef] [PubMed]

75. Ahlfors, H.; Morrison, P.J.; Duarte, J.H.; Li, Y.; Biro, J.; Tolaini, M.; Di Meglio, P.; Potocnik, A.J.; Stockinger, B. IL-22 fate reporter reveals origin and control of IL-22 production in homeostasis and infection. J. Immunol. 2014, 193, 4602-4613. [CrossRef]

76. Melo-Gonzalez, F.; Kammoun, H.; Evren, E.; Dutton, E.E.; Papadopoulou, M.; Bradford, B.M.; Tanes, C.; Fardus-Reid, F.; Swann, J.R.; Bittinger, K.; et al. Antigen-presenting ILC3 regulate T cell-dependent IgA responses to colonic mucosal bacteria. J. Exp. Med. 2019, 216, 728-742. [CrossRef] [PubMed]

77. Abou-Samra, E.; Hickey, Z.; Aguilar, O.A.; Scur, M.; Mahmoud, A.B.; Pyatibrat, S.; Tu, M.M.; Francispillai, J.; Mortha, A.; Carlyle, J.R.; et al. NKR-P1B expression in gut-associated innate lymphoid cells is required for the control of gastrointestinal tract infections. Cell. Mol. Immunol. 2019, 16, 868-877. [CrossRef]

78. Emgård, J.; Kammoun, H.; García-Cassani, B.; Chesné, J.; Parigi, S.M.; Jacob, J.-M.; Cheng, H.-W.; Evren, E.; Das, S.; Czarnewski, P.; et al. Oxysterol Sensing through the Receptor GPR183 Promotes the Lymphoid-Tissue-Inducing Function of Innate Lymphoid Cells and Colonic Inflammation. Immunity 2018, 48, 120-132.e8. [CrossRef]

79. Chu, C.; Moriyama, S.; Li, Z.; Zhou, L.; Flamar, A.-L.; Klose, C.S.N.; Moeller, J.B.; Putzel, G.G.; Withers, D.R.; Sonnenberg, G.F.; et al. Anti-microbial Functions of Group 3 Innate Lymphoid Cells in Gut-Associated Lymphoid Tissues Are Regulated by G-Protein-Coupled Receptor 183. Cell Rep. 2018, 23, 3750-3758. [CrossRef]

80. Stockinger, B.; Di Meglio, P.; Gialitakis, M.; Duarte, J.H. The aryl hydrocarbon receptor: Multitasking in the immune system. Annu. Rev. Immunol. 2014, 32, 403-432. [CrossRef]

81. Li, S.; Bostick, J.W.; Ye, J.; Qiu, J.; Zhang, B.; Urban, J.F.; Avram, D.; Zhou, L. Aryl Hydrocarbon Receptor Signaling Cell Intrinsically Inhibits Intestinal Group 2 Innate Lymphoid Cell Function. Immunity 2018, 49, 915-928.e5. [CrossRef] [PubMed] 
82. Kiss, E.A.; Vonarbourg, C.; Kopfmann, S.; Hobeika, E.; Finke, D.; Esser, C.; Diefenbach, A. Natural aryl hydrocarbon receptor ligands control organogenesis of intestinal lymphoid follicles. Science 2011, 334, 1561-1565. [CrossRef] [PubMed]

83. Lee, J.; Cella, M.; McDonald, K.; Garlanda, C.; Kennedy, G.D.; Nukaya, M.; Mantovani, A.; Kopan, R.; Bradfield, C.A.; Newberry, R.; et al. AHR drives the development of gut ILC22 cells and postnatal lymphoid tissues via pathways dependent on and independent of Notch. Nat. Immunol. 2011, 13, 144-151. [CrossRef] [PubMed]

84. Qiu, J.; Guo, X.; Chen, Z.E.; He, L.; Sonnenberg, G.F.; Artis, D.; Fu, Y.-X.; Zhou, L. Group 3 Innate Lymphoid Cells Inhibit T-Cell-Mediated Intestinal Inflammation through Aryl Hydrocarbon Receptor Signaling and Regulation of Microflora. Immunity 2013, 39. [CrossRef]

85. Van de Pavert, S.A.; Ferreira, M.; Domingues, R.G.; Ribeiro, H.; Molenaar, R.; Moreira-Santos, L.; Almeida, F.F.; Ibiza, S.; Barbosa, I.; Goverse, G.; et al. Maternal retinoids control type 3 innate lymphoid cells and set the offspring immunity. Nature 2014, 508, 123-127. [CrossRef]

86. Spencer, S.; Wilhelm, C.; Yang, Q.; Hall, J.; Bouladoux, N.; Boyd, A.; Nutman, T.; Urban, J.; Wang, J.; Ramalingam, T.; et al. Adaptation of Innate Lymphoid Cells to a Micronutrient Deficiency Promotes Type 2 Barrier Immunity. Science 2014, 343, 432-437. [CrossRef]

87. Goverse, G.; Labao-Almeida, C.; Ferreira, M.; Molenaar, R.; Wahlen, S.; Konijn, T.; Koning, J.; Veiga-Fernandes, H.; Mebius, R.E. Vitamin A Controls the Presence of ROR $\gamma^{+}$Innate Lymphoid Cells and Lymphoid Tissue in the Small Intestine. J. Immunol. 2016, 196, 5148-5155. [CrossRef]

88. Burrows, K.; Antignano, F.; Chenery, A.; Bramhall, M.; Korinek, V.; Underhill, T.M.; Zaph, C. HIC1 links retinoic acid signalling to group 3 innate lymphoid cell-dependent regulation of intestinal immunity and homeostasis. PLoS Pathog. 2018, 14, e1006869. [CrossRef]

89. Chen, J.; Waddell, A.; Lin, Y.-D.; Cantorna, M.T. Dysbiosis caused by vitamin D receptor deficiency confers colonization resistance to Citrobacter rodentium through modulation of innate lymphoid cells. Mucosal Immunol. 2015, 8, 618-626. [CrossRef]

90. Konya, V.; Czarnewski, P.; Forkel, M.; Rao, A.; Kokkinou, E.; Villablanca, E.J.; Almer, S.; Lindforss, U.; Friberg, D.; Höög, C.; et al. Vitamin D downregulates the IL-23 receptor pathway in human mucosal group 3 innate lymphoid cells. J. Allergy Clin. Immunol. 2018, 141, 279-292. [CrossRef]

91. Lin, Y.-D.; Arora, J.; Diehl, K.; Bora, S.A.; Cantorna, M.T. Vitamin D Is Required for ILC3 Derived IL-22 and Protection From Citrobacter rodentium Infection. Front. Immunol. 2019, 10. [CrossRef]

92. Manta, C.; Heupel, E.; Radulovic, K.; Rossini, V.; Garbi, N.; Riedel, C.U.; Niess, J.H. CX ${ }_{3}$ CR1 ${ }^{+}$macrophages support IL-22 production by innate lymphoid cells during infection with Citrobacter rodentium. Mucosal Immunol. 2013, 6, 177-188. [CrossRef]

93. Satoh-Takayama, N.; Serafini, N.; Verrier, T.; Rekiki, A.; Renauld, J.-C.; Frankel, G.; Di Santo, J.P. The Chemokine Receptor CXCR6 Controls the Functional Topography of Interleukin-22 Producing Intestinal Innate Lymphoid Cells. Immunity 2014, 41, 776-788. [CrossRef] [PubMed]

94. Longman, R.S.; Diehl, G.E.; Victorio, D.A.; Huh, J.R.; Galan, C.; Miraldi, E.R.; Swaminath, A.; Bonneau, R.; Scherl, E.J.; Littman, D.R. $\mathrm{CX}_{3} \mathrm{CR} 1^{+}$mononuclear phagocytes support colitis-associated innate lymphoid cell production of IL-22. J. Exp. Med. 2014, 211, 1571-1583. [CrossRef] [PubMed]

95. Kang, L.; Zhang, X.; Ji, L.; Kou, T.; Smith, S.M.; Zhao, B.; Guo, X.; Pineda-Torra, I.; Wu, L.; Hu, X. The colonic macrophage transcription factor RBP-J orchestrates intestinal immunity against bacterial pathogens. J. Exp. Med. 2020, 217. [CrossRef]

96. Wang, B.; Lim, J.-H.; Kajikawa, T.; Li, X.; Vallance, B.A.; Moutsopoulos, N.M.; Chavakis, T.; Hajishengallis, G. Macrophage $\beta 2$-Integrins Regulate IL-22 by ILC3s and Protect from Lethal Citrobacter rodentium-Induced Colitis. Cell Rep. 2019, 26, 1614-1626.e5. [CrossRef] [PubMed]

97. Gatto, D.; Paus, D.; Basten, A.; Mackay, C.R.; Brink, R. Guidance of B cells by the orphan G protein-coupled receptor EBI2 shapes humoral immune responses. Immunity 2009, 31, 259-269. [CrossRef]

98. Li, J.; Lu, E.; Yi, T.; Cyster, J.G. EBI2 augments Tfh cell fate by promoting interaction with IL2-quenching dendritic cells. Nature 2016, 533, 110-114. [CrossRef]

99. Pereira, J.P.; Kelly, L.M.; Xu, Y.; Cyster, J.G. EBV induced molecule-2 mediates B cell segregation between outer and center follicle. Nature 2009, 460, 1122-1126. [CrossRef]

100. Zhou, L. Ahr function in lymphocytes: Emerging concepts. Trends Immunol. 2016, 37, 17-31. [CrossRef] 
101. Xiao, L.; Cui, T.; Liu, S.; Chen, B.; Wang, Y.; Yang, T.; Li, T.; Chen, J. Vitamin A supplementation improves the intestinal mucosal barrier and facilitates the expression of tight junction proteins in rats with diarrhea. Nutrition 2019, 57, 97-108. [CrossRef] [PubMed]

102. Li, Y.; Gao, Y.; Cui, T.; Yang, T.; Liu, L.; Li, T.; Chen, J. Retinoic Acid Facilitates Toll-Like Receptor 4 Expression to Improve Intestinal Barrier Function through Retinoic Acid Receptor Beta. Cell. Physiol. Biochem. Int. J. Exp. Cell. Physiol. Biochem. Pharmacol. 2017, 42, 1390-1406. [CrossRef]

103. Matsunami, N.; Hamaguchi, Y.; Yamamoto, Y.; Kuze, K.; Kangawa, K.; Matsuo, H.; Kawaichi, M.; Honjo, T. A protein binding to the $\mathrm{J} \mathrm{k}$ recombination sequence of immunoglobulin genes contains a sequence related to the integrase motif. Nature 1989, 342, 934-937. [CrossRef] [PubMed]

104. Fachi, J.L.; Sécca, C.; Rodrigues, P.B.; de Mato, F.C.P.; Di Luccia, B.; de Felipe, J.S.; Pral, L.P.; Rungue, M.; de Rocha, V.M.; Sato, F.T.; et al. Acetate coordinates neutrophil and ILC3 responses against C. difficile through FFAR2. J. Exp. Med. 2020, 217. [CrossRef] [PubMed]

105. Behnsen, J.; Jellbauer, S.; Wong, C.P.; Edwards, R.A.; George, M.D.; Ouyang, W.; Raffatellu, M. The cytokine IL-22 promotes pathogen colonization by suppressing related commensal bacteria. Immunity 2014, 40, 262-273. [CrossRef]

106. Coyne, M.J.; Reinap, B.; Lee, M.M.; Comstock, L.E. Human symbionts use a host-like pathway for surface fucosylation. Science 2005, 307, 1778-1781. [CrossRef]

107. Hooper, L.V.; Xu, J.; Falk, P.G.; Midtvedt, T.; Gordon, J.I. A molecular sensor that allows a gut commensal to control its nutrient foundation in a competitive ecosystem. Proc. Natl. Acad. Sci. USA 1999, 96, 9833-9838. [CrossRef]

108. Su, J.; Chai, X.; Kahn, B.; Napoli, J.L. cDNA cloning, tissue distribution, and substrate characteristics of a cis-Retinol/3alpha-hydroxysterol short-chain dehydrogenase isozyme. J. Biol. Chem. 1998, 273, 17910-17916. [CrossRef]

109. Grizotte-Lake, M.; Zhong, G.; Duncan, K.; Kirkwood, J.; Iyer, N.; Smolenski, I.; Isoherranen, N.; Vaishnava, S. Commensals Suppress Intestinal Epithelial Cell Retinoic Acid Synthesis to Regulate Interleukin-22 Activity and Prevent Microbial Dysbiosis. Immunity 2018, 49, 1103-1115.e6. [CrossRef]

110. Maloy, K.J.; Salaun, L.; Cahill, R.; Dougan, G.; Saunders, N.J.; Powrie, F. CD4 ${ }^{+}$CD25 ${ }^{+}$T(R) cells suppress innate immune pathology through cytokine-dependent mechanisms. J. Exp. Med. 2003, 197, 111-119. [CrossRef]

111. Chai, J.N.; Peng, Y.; Rengarajan, S.; Solomon, B.D.; Ai, T.L.; Shen, Z.; Perry, J.S.A.; Knoop, K.A.; Tanoue, T.; Narushima, S.; et al. Helicobacter species are potent drivers of colonic $\mathrm{T}$ cell responses in homeostasis and inflammation. Sci. Immunol. 2017, 2. [CrossRef]

112. Bostick, J.W.; Wang, Y.; Shen, Z.; Ge, Y.; Brown, J.; Chen, Z.-M.E.; Mohamadzadeh, M.; Fox, J.G.; Zhou, L. Dichotomous regulation of group 3 innate lymphoid cells by nongastric Helicobacter species. Proc. Natl. Acad. Sci. USA 2019, 116, 24760-24769. [CrossRef] [PubMed]

113. Freud, A.G.; Yokohama, A.; Becknell, B.; Lee, M.T.; Mao, H.C.; Ferketich, A.K.; Caligiuri, M.A. Evidence for discrete stages of human natural killer cell differentiation in vivo. J. Exp. Med. 2006, 203, 1033-1043. [CrossRef] [PubMed]

114. Mjösberg, J.; Spits, H. Human innate lymphoid cells. J. Allergy Clin. Immunol. 2016, 138, 1265-1276. [CrossRef] [PubMed]

115. Saluzzo, S.; Gorki, A.-D.; Rana, B.M.J.; Martins, R.; Scanlon, S.; Starkl, P.; Lakovits, K.; Hladik, A.; Korosec, A.; Sharif, O.; et al. First-Breath-Induced Type 2 Pathways Shape the Lung Immune Environment. Cell Rep. 2017, 18, 1893-1905. [CrossRef] [PubMed]

116. Van der Poll, T.; Opal, S.M. Pathogenesis, treatment, and prevention of pneumococcal pneumonia. Lancet Lond. Engl. 2009, 374, 1543-1556. [CrossRef]

117. Moore, T.A.; Perry, M.L.; Getsoian, A.G.; Newstead, M.W.; Standiford, T.J. Divergent Role of Gamma Interferon in a Murine Model of Pulmonary versus Systemic Klebsiella pneumoniae Infection. Infect. Immun. 2002, 70, 6310-6318. [CrossRef]

118. Xiong, H.; Keith, J.W.; Samilo, D.W.; Carter, R.A.; Leiner, I.M.; Pamer, E.G. Innate Lymphocyte/Ly6C(hi) Monocyte Crosstalk Promotes Klebsiella Pneumoniae Clearance. Cell 2016, 165, 679-689. [CrossRef]

119. Ivin, M.; Dumigan, A.; de Vasconcelos, F.N.; Ebner, F.; Borroni, M.; Kavirayani, A.; Przybyszewska, K.N.; Ingram, R.J.; Lienenklaus, S.; Kalinke, U.; et al. Natural killer cell-intrinsic type I IFN signaling controls Klebsiella pneumoniae growth during lung infection. PLoS Pathog. 2017, 13. [CrossRef] 
120. Van der Maas, N.A.T.; Mooi, F.R.; de Greeff, S.C.; Berbers, G.A.M.; Spaendonck, M.A.E.C.; de Melker, H.E. Pertussis in the Netherlands, is the current vaccination strategy sufficient to reduce disease burden in young infants? Vaccine 2013, 31, 4541-4547. [CrossRef]

121. Tan, T.; Dalby, T.; Forsyth, K.; Halperin, S.A.; Heininger, U.; Hozbor, D.; Plotkin, S.; Ulloa-Gutierrez, R.; Wirsing von König, C.H. Pertussis Across the Globe: Recent Epidemiologic Trends From 2000 to 2013. Pediatr. Infect. Dis. J. 2015, 34, e222-e232. [CrossRef] [PubMed]

122. Byrne, P.; McGuirk, P.; Todryk, S.; Mills, K.H.G. Depletion of NK cells results in disseminating lethal infection with Bordetella pertussis associated with a reduction of antigen-specific Th1 and enhancement of Th2, but not Tr1 cells. Eur. J. Immunol. 2004, 34, 2579-2588. [CrossRef] [PubMed]

123. Mahon, B.P.; Sheahan, B.J.; Griffin, F.; Murphy, G.; Mills, K.H. Atypical disease after Bordetella pertussis respiratory infection of mice with targeted disruptions of interferon-gamma receptor or immunoglobulin mu chain genes. J. Exp. Med. 1997, 186, 1843-1851. [CrossRef] [PubMed]

124. Kroes, M.M.; Mariman, R.; Hijdra, D.; Hamstra, H.-J.; van Boxtel, K.J.W.M.; van Putten, J.P.M.; de Wit, J.; Pinelli, E. Activation of Human NK Cells by Bordetella pertussis Requires Inflammasome Activation in Macrophages. Front. Immunol. 2019, 10. [CrossRef] [PubMed]

125. Huang, Y.; Lei, Y.; Zhang, H.; Zhang, M.; Dayton, A. Role of interleukin-18 in human natural killer cell is associated with interleukin-2. Mol. Immunol. 2010, 47, 2604-2610. [CrossRef]

126. Wawrocki, S.; Druszczynska, M.; Kowalewicz-Kulbat, M.; Rudnicka, W. Interleukin 18 (IL-18) as a target for immune intervention. Acta Biochim. Pol. 2016, 63, 59-63. [CrossRef]

127. Murakami, T.; Hatano, S.; Yamada, H.; Iwakura, Y.; Yoshikai, Y. Two Types of Interleukin 17A-Producing $\gamma \delta$ T Cells in Protection against Pulmonary Infection with Klebsiella pneumoniae. J. Infect. Dis. 2016, 214, 1752-1761. [CrossRef]

128. Chen, K.; Eddens, T.; Trevejo-Nunez, G.; Way, E.E.; Elsegeiny, W.; Ricks, D.M.; Garg, A.V.; Erb, C.J.; Bo, M.; Wang, T.; et al. IL-17 receptor signaling in the lung epithelium is required for mucosal chemokine gradients and pulmonary host defense against K. pneumoniae. Cell Host Microbe 2016, 20, 596-605. [CrossRef]

129. Xu, X.; Weiss, I.D.; Zhang, H.H.; Singh, S.P.; Wynn, T.A.; Wilson, M.S.; Farber, J.M. Conventional NK cells can produce IL-22 and promote host defense in Klebsiella pneumoniae pneumonia. J. Immunol. 2014, 192, 1778-1786. [CrossRef]

130. Van Maele, L.; Carnoy, C.; Cayet, D.; Ivanov, S.; Porte, R.; Deruy, E.; Chabalgoity, J.A.; Renauld, J.-C.; Eberl, G.; Benecke, A.G.; et al. Activation of Type 3 innate lymphoid cells and interleukin 22 secretion in the lungs during Streptococcus pneumoniae infection. J. Infect. Dis. 2014, 210, 493-503. [CrossRef]

131. Kinnebrew, M.A.; Buffie, C.G.; Diehl, G.E.; Zenewicz, L.A.; Leiner, I.; Hohl, T.M.; Flavell, R.A.; Littman, D.R.; Pamer, E.G. Interleukin 23 production by intestinal $C D 103^{+} \mathrm{CD} 11 \mathrm{~b}^{+}$dendritic cells in response to bacterial flagellin enhances mucosal innate immune defense. Immunity 2012, 36, 276-287. [CrossRef] [PubMed]

132. Van Maele, L.; Carnoy, C.; Cayet, D.; Songhet, P.; Dumoutier, L.; Ferrero, I.; Janot, L.; Erard, F.; Bertout, J.; Leger, H.; et al. TLR5 signaling stimulates the innate production of IL-17 and IL-22 by CD3(neg)CD127+ immune cells in spleen and mucosa. J. Immunol. 2010, 185, 1177-1185. [CrossRef] [PubMed]

133. Gray, J.; Oehrle, K.; Worthen, G.; Alenghat, T.; Whitsett, J.; Deshmukh, H. Intestinal Commensal Bacteria Mediate Lung Mucosal Immunity and Promote Resistance of Newborn Mice to Infection. Sci. Transl. Med. 2017, 9. [CrossRef]

134. Bayes, H.K.; Ritchie, N.D.; Evans, T.J. Interleukin-17 Is Required for Control of Chronic Lung Infection Caused by Pseudomonas aeruginosa. Infect. Immun. 2016, 84, 3507-3516. [CrossRef] [PubMed]

135. Broquet, A.; Jacqueline, C.; Davieau, M.; Besbes, A.; Roquilly, A.; Martin, J.; Caillon, J.; Dumoutier, L.; Renauld, J.-C.; Heslan, M.; et al. Interleukin-22 level is negatively correlated with neutrophil recruitment in the lungs in a Pseudomonas aeruginosa pneumonia model. Sci. Rep. 2017, 7, 11010. [CrossRef] [PubMed]

136. Iwanaga, N.; Sandquist, I.; Wanek, A.; McCombs, J.; Song, K.; Kolls, J.K. Host immunology and rational immunotherapy for carbapenem-resistant Klebsiella pneumoniae infection. JCI Insight 2020, 5. [CrossRef]

137. Global Tuberculosis Report. 2019. Available online: https://www.who.int/tb/publications/global_report/en/ (accessed on 29 June 2020).

138. Rosain, J.; Kong, X.-F.; Martinez-Barricarte, R.; Oleaga-Quintas, C.; Ramirez-Alejo, N.; Markle, J.; Okada, S.; Boisson-Dupuis, S.; Casanova, J.-L.; Bustamante, J. Mendelian susceptibility to mycobacterial disease: 2014-2018 update. Immunol. Cell Biol. 2019, 97, 360-367. [CrossRef] 
139. Ardain, A.; Domingo-Gonzalez, R.; Das, S.; Kazer, S.W.; Howard, N.C.; Singh, A.; Ahmed, M.; Nhamoyebonde, S.; Rangel-Moreno, J.; Ogongo, P.; et al. Group 3 innate lymphoid cells mediate early protective immunity against tuberculosis. Nature 2019, 570, 528-532. [CrossRef]

140. Slight, S.R.; Rangel-Moreno, J.; Gopal, R.; Lin, Y.; Fallert Junecko, B.A.; Mehra, S.; Selman, M.; Becerril-Villanueva, E.; Baquera-Heredia, J.; Pavon, L.; et al. CXCR5 ${ }^{+}$T helper cells mediate protective immunity against tuberculosis. J. Clin. Investig. 2013, 123, 712-726. [CrossRef]

141. Rafei-Shamsabadi, D.A.; Klose, C.S.N.; Halim, T.Y.F.; Tanriver, Y.; Jakob, T. Context Dependent Role of Type 2 Innate Lymphoid Cells in Allergic Skin Inflammation. Front. Immunol. 2019, 10, 2591. [CrossRef]

142. Salimi, M.; Barlow, J.L.; Saunders, S.P.; Xue, L.; Gutowska-Owsiak, D.; Wang, X.; Huang, L.-C.; Johnson, D.; Scanlon, S.T.; McKenzie, A.N.J.; et al. A role for IL-25 and IL-33-driven type-2 innate lymphoid cells in atopic dermatitis. J. Exp. Med. 2013, 210, 2939-2950. [CrossRef] [PubMed]

143. Salimi, M.; Xue, L.; Jolin, H.; Hardman, C.; Cousins, D.J.; McKenzie, A.N.J.; Ogg, G.S. Group 2 Innate Lymphoid Cells Express Functional NKp30 Receptor Inducing Type 2 Cytokine Production. J. Immunol. 2016, 196, 45-54. [CrossRef]

144. Roediger, B.; Kyle, R.; Yip, K.H.; Sumaria, N.; Guy, T.V.; Kim, B.S.; Mitchell, A.J.; Tay, S.S.; Jain, R.; Forbes-Blom, E.; et al. Cutaneous immunosurveillance and regulation of inflammation by group 2 innate lymphoid cells. Nat. Immunol. 2013, 14, 564-573. [CrossRef] [PubMed]

145. Gong, J.Q.; Lin, L.; Lin, T.; Hao, F.; Zeng, F.Q.; Bi, Z.G.; Yi, D.; Zhao, B. Skin colonization by Staphylococcus aureus in patients with eczema and atopic dermatitis and relevant combined topical therapy: A double-blind multicentre randomized controlled trial. Br. J. Dermatol. 2006, 155, 680-687. [CrossRef]

146. Hardman, C.S.; Chen, Y.-L.; Salimi, M.; Jarrett, R.; Johnson, D.; Järvinen, V.J.; Owens, R.J.; Repapi, E.; Cousins, D.J.; Barlow, J.L.; et al. CD1a presentation of endogenous antigens by group 2 innate lymphoid cells. Sci. Immunol. 2017, 2. [CrossRef] [PubMed]

147. Singer, M.; Deutschman, C.S.; Seymour, C.W.; Shankar-Hari, M.; Annane, D.; Bauer, M.; Bellomo, R.; Bernard, G.R.; Chiche, J.-D.; Coopersmith, C.M.; et al. The Third International Consensus Definitions for Sepsis and Septic Shock (Sepsis-3). JAMA 2016, 315, 801-810. [CrossRef] [PubMed]

148. Mira, J.C.; Gentile, L.F.; Mathias, B.J.; Efron, P.A.; Brakenridge, S.C.; Mohr, A.M.; Moore, F.A.; Moldawer, L.L. Sepsis Pathophysiology, Chronic Critical Illness and PICS. Crit. Care Med. 2017, 45, 253-262. [CrossRef]

149. Carvelli, J.; Piperoglou, C.; Bourenne, J.; Farnarier, C.; Banzet, N.; Demerlé, C.; Gainnier, M.; Vély, F. Imbalance of Circulating Innate Lymphoid Cell Subpopulations in Patients with Septic Shock. Front. Immunol. 2019, 10. [CrossRef]

150. Nedeva, C.; Menassa, J.; Puthalakath, H. Sepsis: Inflammation Is a Necessary Evil. Front. Cell Dev. Biol. 2019, 7. [CrossRef]

151. Cruz-Zárate, D.; Cabrera-Rivera, G.L.; Ruiz-Sánchez, B.P.; Serafín-López, J.; Chacón-Salinas, R.; López-Macías, C.; Isibasi, A.; Gallegos-Pérez, H.; León-Gutiérrez, M.A.; Ferat-Osorio, E.; et al. Innate Lymphoid Cells Have Decreased HLA-DR Expression but Retain Their Responsiveness to TLR Ligands during Sepsis. J. Immunol. 2018, 201, 3401-3410. [CrossRef]

152. Chun, T.T.; Chung, C.-S.; Fallon, E.A.; Hutchins, N.A.; Clarke, E.; Rossi, A.-L.; Cioffi, W.G.; Heffernan, D.S.; Ayala, A. Group 2 Innate Lymphoid Cells (ILC2s) Are Key Mediators of the Inflammatory Response in Polymicrobial Sepsis. Am. J. Pathol. 2018, 188, 2097-2108. [CrossRef] [PubMed]

153. Nascimento, D.C.; Melo, P.H.; Piñeros, A.R.; Ferreira, R.G.; Colón, D.F.; Donate, P.B.; Castanheira, F.V.; Gozzi, A.; Czaikoski, P.G.; Niedbala, W.; et al. IL-33 contributes to sepsis-induced long-term immunosuppression by expanding the regulatory $\mathrm{T}$ cell population. Nat. Commun. 2017, 8, 14919. [CrossRef] [PubMed]

154. Lai, D.; Tang, J.; Chen, L.; Fan, E.K.; Scott, M.J.; Li, Y.; Billiar, T.R.; Wilson, M.A.; Fang, X.; Shu, Q.; et al. Group 2 innate lymphoid cells protect lung endothelial cells from pyroptosis in sepsis. Cell Death Dis. 2018, 9, 369. [CrossRef] [PubMed]

(C) 2020 by the authors. Licensee MDPI, Basel, Switzerland. This article is an open access article distributed under the terms and conditions of the Creative Commons Attribution (CC BY) license (http://creativecommons.org/licenses/by/4.0/). 